\title{
The scientific rationale and clinical application of short-chain fatty acids and medium-chain triacylglycerols
}

\author{
BY OMAIDA C. VELÁZQUEZ, RENÉE W. SETO \\ AND JOHN L. ROMBEAU \\ Harrison Department of Surgical Research and Department of Surgery, Hospital of the University \\ of Pennsylvania, University of Pennsylvania Medical Center, Philadelphia, PA 19104, USA
}

\section{Bases scientifiques et applications cliniques des lipides à chaîne courte et des triacylglycérols à chaîne moyenne}

\section{RÉSUMÉ}

Cette revue discute les bases scientifiques et les applications cliniques des lipides à chaîne courte (LCC) et des triacylglycérols à chaîne moyenne (TCM).

Les LCC sont produits dans le côlon des mammifères à la suite de la fermentation microbienne des fibres, de l'amidon non digéré, et des protéines de l'alimentation. Leur concentration dans les segments différents du côlon est affectée par l'apport alimentaire; ceci a des effets métaboliques importants sur le colonocyte. Le butyrate, un des trois LCC les plus importants, a été impliqué comme agent protecteur dans la pathogénèse du cancer du côlon. Les LCC stimulent l'absorption du chlorure de Na et de l'eau dans la lumière du côlon. Le butyrate a des effets trophiques sur la muqueuse normale du côlon in vivo et stimule la prolifération physiologique des colonocytes normaux in vitro. En revanche, il bloque la croissance des colonocytes néoplastiques et inhibe l'hyperprolifération prénéoplastique induite par certains carcinogènes in vitro. Le butyrate induit une différenciation histologique des lignées cellulaires du cancer du côlon en parallèle avec des augmentations dans l'expression des marqueurs de la différenciation des colonocytes. Il inhibe également l'expression de plusieurs protooncogènes importants dans la carcinogénèse colorectale. Des études plus poussées s'imposent pour évaluer les effets thérapeutiques potentiels du butyrate in vivo, et pour comprendre son ou ses mécanismes d'action.

Les émulsions de lipides disponibles se composent de triacylglycérols à chaîne longues (TCL) qui fournissent de l'énergie aussi bien que des acides gras essentiels tels que l'acide linoléique. Cependant, le métabolisme des TCL est plus lent que celui des TCM, et plus de $50 \%$ des lipides dérivés des TCL sont stockés sous forme de graisses, au lieu d'être oxydées pour fournir de l'énergie. Une oxydation rapide, un transport indépendant de la carnitine vers les mitochondries (site de cette oxydation), et la capacité de fournir un apport rapide d'énergie par deux mécanismes ( $\beta$-oxydation et formation de corps cétoniques), font des TCM une source d'énergie théoriquement avantageuse (en particulier dans le cas d'états cliniques déficients en carnitine tels que les traumatismes, les états septiques ou les chocs graves). 
Short-chain fatty acids (SCFA) are the $\mathrm{C}_{2-5}$ organic fatty acids. These compounds are formed in the gastrointestinal tract of mammals as a result of anaerobic bacterial fermentation of undigested dietary components (Wolin, 1981; Wrong, 1981; Cummings \& Branch, 1990). Although dietary fibre is the principal substrate for fermentation to SCFA in human subjects (Rombeau et al. 1990), undigested starch and protein also contribute to their production (Macfarlane et al. 1994). In the mammalian hindgut acetate, propionate and butyrate account for $83 \%$ of SCFA, with a total concentration of approximately $100 \mathrm{mmol} / \mathrm{l}$ (Nyman \& Asp, 1982; Demigné \& Rémésy, 1985; Rechkemmer et al. 1988) and are present in a nearly constant molar ratio of $60: 25: 15$ respectively (Cummings \& Branch, 1990). The highest concentrations of SCFA (120 $\mathrm{mmol} / \mathrm{l}$ ) in humans are usually found in the caecum (Cummings et al. 1987).

The total concentration, as well as the relative molar concentrations of individual SCFA, are greatly influenced by dietary carbohydrates and proteins (Wolin, 1981; Wrong, 1981; Cummings et al. 1987; Mortensen et al. 1990; Macfarlane et al. 1992). Proteins are preferentially fermented to $n$-valerate, iso-valerate, and 2-methylbutyrate (Macfarlane et al. 1992). The fact that different dietary substrates are preferentially fermented to different SCFA may be important in the relationship between diet and colonic pathology.

SCFA maintain the integrity of the intestinal mucosa (Roediger, 1980a), and stimulate proliferation of normal colonocytes (Jacobs, 1983). They are avidly absorbed by the normal intestinal epithelium (Cummings et al. 1987) and stimulate water and electrolyte absorption from the colonic lumen in animals and human subjects both in vitro and in vivo (Roediger, 1980a; Ruppin et al. 1980; Binder \& Mehta, 1989; Bowling et al. 1993; Rajendran \& Binder, 1994). Butyrate is the preferred oxidative fuel of colonocytes over glucose, glutamine or ketone bodies (Roediger, 1982).

Epidemiological studies suggest that dietary fat and protein may promote carcinogenesis in the colon, whereas increased fibre and complex carbohydrates in the diet may protect against colon cancer (Jacobs, 1986, 1988, 1990; Lee et al. 1993; McIntyre et al. 1993; Van Munster \& Nagengast, 1993). Human case-control studies support this association (Howe et al. 1992). Intake of fibre-rich foods is inversely related to risk of both colon and rectal cancer (Howe et al. 1992). Colonic lumen butyrate concentrations are postulated to be a key protective component of high-fibre diets against colon cancer (McIntyre et al. 1993; Van Munster \& Nagengast, 1993).

Butyrate modulates normal and neoplastic colonocyte growth and differentiation in animals (Otaka et al. 1989; Young, 1990; McIntyre et al. 1993), and in human cells in vitro (Kim et al. 1980; Tsao et al. 1982; Dexter et al. 1984; Whitehead et al. 1986; Czerniak et al. 1987; Gibson \& Pavli, 1992; Scheppach et al. 1992a; Souleimani \& Asselin, 1992; Bartram et al. 1993, 1995; Scheppach, 1994). The effects of propionate on colonocyte growth and differentiation are similar to those of butyrate, but less marked; acetate does not exert these effects.

The present article reviews the production, absorption and metabolism of SCFA as well as their effects on normal and neoplastic colonocyte growth and differentiation. The known and hypothetical molecular events behind the mechanism of action of butyrate are detailed. The available data are examined in relation to their implications for understanding, preventing and treating colonic pathology such as diversion colitis, ulcerative colitis, enteral-feeding-induced diarrhoea, and colon cancer. Finally, the scientific rationale and clinical applications for the use of medium-chain triacylglycerols (MCT) are reviewed. 


\section{SHORT-CHAIN FATTY ACID PRODUCTION}

Although there are considerable variations in hindgut volume between carnivores, omnivores and herbivores, all mammals extensively ferment polysaccharides via anaerobic bacteria in the hindgut.

\section{Production in animals}

Studies of different dietary fibre intakes in rats indicate that high-fibre diets significantly increase microbial growth in the colon and influence the molar ratios of SCFA produced (Maczulak et al. 1983). Daily faecal output of total viable anaerobes is seventy-one times higher in high-fibre-fed rats. The excretion of total fermentation products is $2.4 \mathrm{v.} 0 \cdot 1$ mmol for high-fibre diets and fibre-free diets respectively. Molar ratios for acetate: propionate:butyrate are 69:21:10 v. 92:7:1 in the high-fibre and fibre-free groups respectively (Maczulak et al. 1983). In vivo rat colonic lumen concentrations of butyrate may reach as high as $30 \mathrm{mmol} / \mathrm{l}$ (McIntyre et al. 1991) with dietary fibre supplementation.

A study using newborn piglets demonstrates limited production of SCFA as early as the first day of life. SCFA levels are low and stable between days 5 and 14, and then abruptly accumulate in the lumen after $14 \mathrm{~d}$ of life when colonic anaerobic flora achieve near adult-like population. Acetate is predominantly formed early, while propionate and butyrate are seen as late peaks. The major sites of production and absorption of SCFA in this model are proximal to the left colon (Murray et al. 1987).

\section{Production in human subjects}

Studies with human subjects have shown that neonates produce acetate, propionate, butyrate and other acids in the ratio 89:5:5:1 respectively by the end of $4 \mathrm{~d}$ (Rasmussen et al. 1988). The corresponding adult fermentation ratio is $55: 18: 11: 6$, which is consistent with postnatal microbial colonization of the human neonatal colon (Rasmussen et al. 1988).

The occurrence of microbial breakdown of carbohydrate and protein to SCFA in the human adult colon has been evaluated by obtaining large-intestine stool samples and portal, hepatic and peripheral venous blood samples from sudden-death victims, within 4 $\mathrm{h}$ of death (Cummings et al. 1987). Total SCFA concentrations (mmol/l) are low in the terminal ileum (13 (1SE 6)) and high in the colon, ranging from 131 (1SE 1) in the caecum to 80 (1SE 11) in the descending colon. These findings demonstrate a significant decreasing trend from caecum to descending colon, with an associated trend of increasing $\mathrm{pH}$ from the caecum $(5 \cdot 6(1 \mathrm{SE} 0 \cdot 2))$ to the descending colon $(6 \cdot 6(1 \mathrm{SE} 0 \cdot 1))$. Acetate, propionate and butyrate production, as well as branched-chain fatty acid production, is found. Total SCFA concentrations measured in the blood ( $\mathrm{mmol} / \mathrm{l})$ are portal (375 (1SE 70)), hepatic (148 (1SE 42)) and peripheral (79 (1SE 22)). In this study, the molar ratios for the three principal SCFA recovered at the different sites tested indicate a preferential and greater uptake of butyrate (over other SCFA) by the colonic epithelium (Cummings et al. 1987).

\section{Influence of dietary substrate on fermentation patterns}

When attempting to manipulate colonic levels of butyrate it should be noted that 
butyrate administered orally is absorbed before reaching the colon (Young \& Gibson, 1994). Tributyrin and butyrate esters taken orally increase the butyrate concentration in the proximal colon of animals, but these compounds are expensive (Young \& Gibson, 1994). A more physiological approach to increasing the butyrate concentration in the lumen of both the proximal and distal colon is by dietary manipulation which relies on bacterial fermentation of fibre (Topping et al. 1993). Butyrate is known to inhibit histone deacetylase leading to histone hyperacetylation in vitro (Boffa et al. 1978). In a study which modulated the concentration of butyrate in rat distal colon in vivo, a significant correlation between lumen butyrate levels and histone hyperacetylation was demonstrated in colonocytes (Boffa et al. 1992). These investigators were able to modulate colon butyrate levels by adding wheat bran to the diet. It appears, therefore, that dietary chemo-prevention (the ability to manipulate colonic butyrate levels with diet) may be a feasible goal (Jacobs, 1988).

Fermentation of some types of fibre consistently leads to increased proportions of butyrate production. Fermentation of soyabean fibre leads to higher proportions of butyrate and propionate than do citrus pectin, sugarbeet fibre, pea (Pisum sativum) fibre, and oat fibre (Titgemeyer et al. 1991). Fermentation of gums produces more butyrate and propionate than apple pectin (Titgemeyer et al. 1991). Oat bran, but not a $\beta$-glucan-enriched oat fraction, enhances butyrate production in the pig large intestine (Knudsen et al. 1993). This study indicated that arabinoxylan, and not $\beta$-glucan, in the cell walls of oat bran is responsible for the enhanced butyrate production of oat bran. Maize-starch fermentation by human colonic faecal suspensions yields more butyrate than cabbage fibre fermentation in samples obtained from twenty human subjects (Weaver et al. 1992). Slowly-fermentable fibre such as wheat bran is more effective than completely-fermentable fibre such as oat bran in producing high levels of butyrate throughout the proximal and distal colon in rats (McIntyre et al. 1991) and human subjects (Kashtan et al. 1992). Therefore, it may be possible to manipulate fibre sources in the diet to achieve desired amounts of total and individual SCFA production in the colon. Moreover, most of the studies indicate that variations in SCFA production are more likely to be related to the type of substrate fermented than to the individual tested.

\section{SHORT-CHAIN FATTY ACID ABSORPTION AND EFFECTS ON WATER AND ELECTROLYTES}

SCFA are weak acids with $\mathrm{pK}_{\mathrm{a}}$ of $4.75,4.87$, and 4.81 for acetate, propionate, and butyrate respectively. More than $90 \%$ of the SCFA produced in the mammalian hindgut exist in anionic (or dissociated) form. These compounds constitute the major anions in the fluid phase of the colonic lumen (Engelhardt \& Rechkemmer, 1983). SCFA are rapidly absorbed by the colonic mucosa in vivo, and enhance colonic $\mathrm{Na}, \mathrm{Cl}^{-}, \mathrm{Ca}$ and fluid absorption, and K secretion (Argenzio et al. 1977; McNeil et al. 1978; Argenzio \& Whipp, 1979; Umesaki et al. 1979; Ruppin et al. 1980; Hoverstad, 1986; Binder \& Mehta, 1989, 1990; Longo et al. 1991; Lutz \& Sharrer, 1991; Sellin et al. 1993). This SCFA absorption in association with fluid and electrolyte fluxes are noted in horse (Argenzio et al. 1977), pig (Argenzio \& Whipp, 1979), goat (Argenzio et al. 1975), sheep (Rübsamen et al. 1982), dog (Herschel et al. 1981), rabbit (Marty \& Vernay, 1984), rat (Umesaki et al. 1979) and human subjects (Ruppin et al. 1980; Hoverstad, 1986; Bowling et al. 1993). 


\section{Absorption of short-chain fatty acids: proximal $\mathrm{v}$. distal colon}

Regional differences in the absorption of SCFA are noted in several experimental models (Ruppin et al. 1980; Engelhardt \& Rechkemmer, 1983; Jacobs, 1983; Luciano et al. 1984; Stevens, 1988; Binder \& Mehta, 1989; Sellin et al. 1993) including pig (Argenzio \& Whipp, 1979), rabbit (Vernay, 1987), and guinea-pig (Rechkemmer et al. 1988). SCFA absorbed from the gut are transported via the portal vein and become important metabolic fuels for the liver (Topping et al. 1993).

Animal studies suggest that absorption of SCFA in the proximal colon takes place via three mechanisms: (1) the passive absorption of the lipid-soluble undissociated form, probably coupled to a $\mathrm{Na}^{+}-\mathrm{H}^{+}$exchange; (2) a SCFA- $-\mathrm{HCO}_{3}^{-}$exchange; (3) the diffusion of the anionic form through paracellular 'leaky spots' (when transepithelial conductance is markedly increased by some secretory stimuli; Argenzio \& Whipp, 1979; Luciano et al. 1984; Rechkemmer et al. 1988; Engelhardt, 1995). In the proximal colon (see Fig. 1(a)), 50\% of SCFA are transported in the dissociated form and $50 \%$ in the undissociated form, according to measurements of diffusion potentials across isolated epithelium of guinea-pigs (Rönnau et al. 1989). In the distal colon, the absorption of SCFA was found to be primarily based on diffusion of the free acids in the lipid-soluble undissociated form (Ruppin et al. 1980; Engelhardt, 1995; see Fig. 1(b)). Non-ionic diffusion probably takes place after protonation of the SCFA provided by the $\mathrm{Na}^{+}-\mathrm{H}^{+}$ and $\mathrm{H}^{+}-\mathrm{K}^{+}$exchange mechanisms on the apical membrane (Jacobs, 1983). The source of the $\mathrm{H}^{+}$needed for the absorption of the SCFA in the undissociated form is believed to be supplied by the $\mathrm{Na}^{+}-\mathrm{H}^{+}$exchange and the $\mathrm{HCO}_{3}{ }^{-}$gain system (Engelhardt \& Rechkemmer, 1983), from the $\mathrm{K}^{+}-\mathrm{H}^{+}$pump in the apical membrane of the distal colon (Rechkemmer et al. 1988), and a small proportion provided by the bulk lumen solution.

\section{Effect of lumen $\mathrm{pH}$ in short-chain fatty acid absorption}

In the pH partition hypothesis (Jacobs, 1940; Shore et al. 1957; Hogben et al. 1959) the absorption of SCFA increases with decreasing $\mathrm{pH}$ because of increased concentrations of the lipid-soluble undissociated form of the SCFA. Simultaneously-perfused proximal and distal segments of colon used in anaesthetized guinea-pigs (Rechkemmer \& Engelhardt, 1988) demonstrated that the clearance of SCFA was independent of bulk lumen $\mathrm{pH}$, between $\mathrm{pH} 6.2$ and 8.1 in both the proximal and distal colon. There was slightly higher clearance of SCFA at pH below 6 . These unexpected findings were attributed to the existence of a presumed constant $\mathrm{pH}$ micro-climate at the surface of the colonic epithelium (Rechkemmer et al. 1986; Rechkemmer \& Engelhardt, 1988). The pH of the micro-climate was found to be independent of the bulk lumen $\mathrm{pH}$ and close to neutral in both the proximal and distal colon, pH 7.08 and 6.91 respectively (Rechkemmer et al. 1986).

\section{Effect of short-chain fatty acid chain length on absorption}

According to data compiled on the partition coefficient of weak electrolytes, the permeability of SCFA should increase by 3- -5 -fold with each additional $\mathrm{CH}_{2}$ group if absorption is primarily in the lipid-soluble undissociated form (Walter \& Gutknecht, 1984). However, the absorption of SCFA in the proximal colon shows little relationship to chain length, indicating that lipid solubility at physiological $\mathrm{pH}$ plays only a partial 
(a)

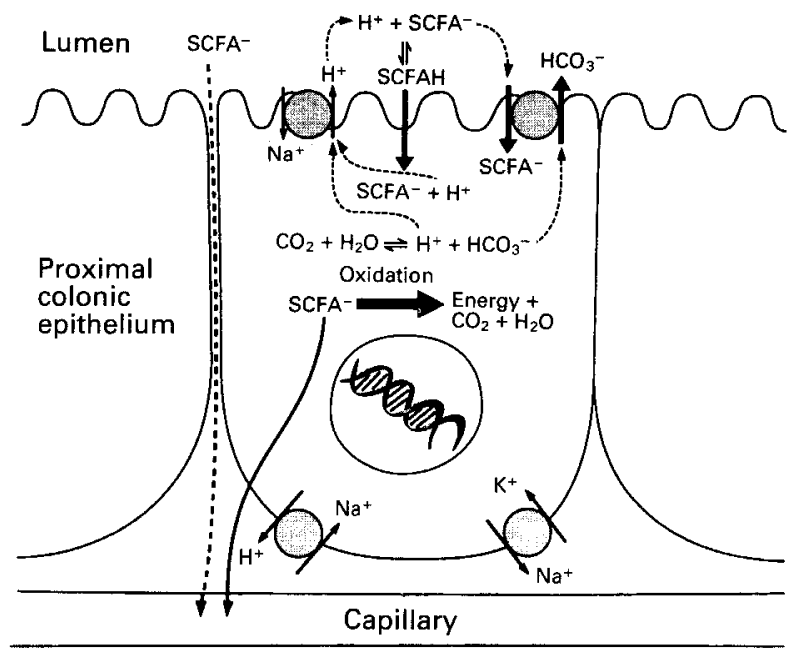

(b)

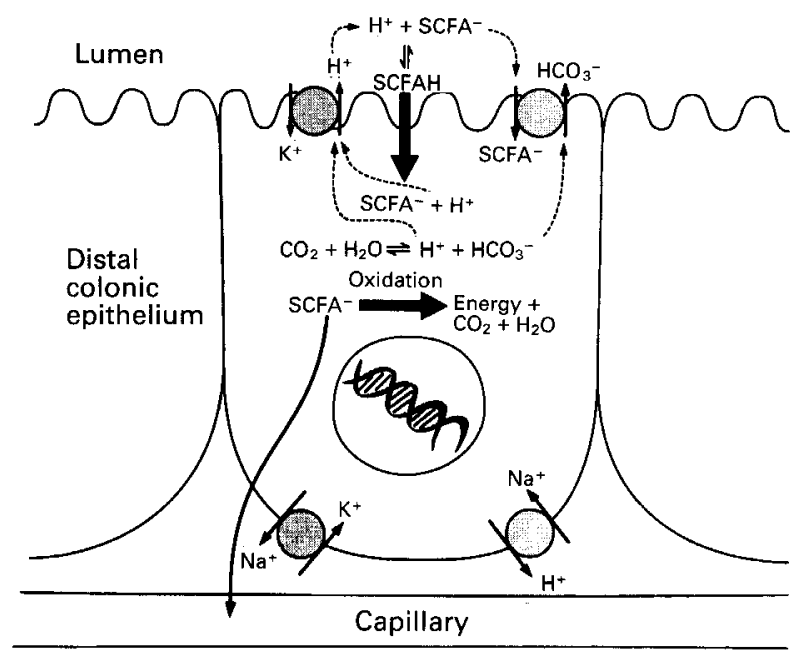

Fig. 1. Simplified, composite model of absorption and metabolism of short-chain fatty acids (SCFA) in (a) the proximal colonic epithelium and (b) the distal colonic epithelium. SCFA ${ }^{-}$, dissociated form; SCFAH, undissociated form. In the proximal colonic epithelium the two main mechanisms for absorption are (1) passive diffusion of the lipid-soluble SCFAH coupled to $\mathrm{Na}^{+}-\mathrm{H}^{+}$exchange and (2) the transport of the ionic form via an $\mathrm{SCFA}^{-}-\mathrm{HCO}_{3}^{-}$exchange. A third, less-important mechanism seen is the paracellular transport of the $\mathrm{SCFA}^{-}$in special conditions where transepithelial conductance is increased by secretory stimuli. In the distal colonic epithelium the main mechanism of absorption is passive diffusion of the lipid-soluble SCFAH coupled to $\mathrm{Na}^{+}-\mathrm{H}^{+}$exchange. (Adapted and reproduced with permission from Engelhardt, 1995.)

role. The permeability of the proximal colon is higher for acetate, equal for propionate, and lower for butyrate when compared with the permeability in the distal colon. It is believed that these permeability differences can be accounted for by the partial absorption of SCFA in the dissociated form in the proximal colon (Engelhardt, 1995). 


\section{Effects of short-chain fatty acids on water and electrolyte absorption}

In vitro studies using isolated pig mucosa from the proximal and distal colon show that $\mathrm{Na}$ absorption is enhanced in the proximal colon with the addition of SCFA. This stimulation is concentration-dependent and follows Michaelis-Menten kinetics (Holtug et al. 1992).

Compared with the distal colon the proximal colon has twice the capacity to absorb $\mathrm{Na}$ and twice the capacity to secrete $\mathrm{H}^{+}$in the presence of SCFA (Roediger et al. 1986). These observations support the hypothesis that enhancement of $\mathrm{Na}$ absorption by free fatty acids is coupled to a $\mathrm{Na}^{+}-\mathrm{H}^{+}$exchange mechanism in the proximal colon (Wrong, 1981; Engelhardt, 1995). The activity of carbonic anhydrase (EC 4.2.1.1) is important in supplying $\mathrm{H}^{+}$for the coupled absorption of Na and SCFA (Rübsamen et al. 1982; Engelhardt, 1995) (see Figs. 1 (a and b)).

An in vivo lumen perfusion technique in rat colon demonstrates that in the proximal colon butyrate significantly enhances $\mathrm{Na}$ and water absorption, while not influencing $\mathrm{Ca}$ absorption (Lutz \& Sharrer, 1991). In the distal colon, however, butyrate and acetate significantly increase $\mathrm{Ca}$ absorption, while $\mathrm{Na}$ and water absorption is not affected. It is postulated that a $\mathrm{Ca}-\mathrm{H}$ exchanger mechanism exists at the apical membrane of the distal colon which mediates $\mathrm{Ca}$ uptake into the epithelial cell.

\section{Short-chain fatty acids and enteral-feeding-related diarrhoea}

Evidence suggests that colonic secretion of water and electrolytes plays an important role in the pathogenesis of enteral-feeding-related diarrhoea (Bowling et al. 1993). Whether or not fibre should be added to artificial enteral nutrition is an issue that continues to be studied (Silk, 1989; Scheppach et al. 1990; Scheppach \& Bartram, 1993). Initial work on SCFA and colonic fluid and electrolyte movement indicated that SCFA are involved in causing diarrhoea and producing fluid and electrolyte secretion (Bustos-Fernandez et al. 1971). Subsequent work, however, showed that SCFA are not involved in the pathogenesis of diarrhoea, and are responsible for compensatory and conservation mechanisms in some diarrhoea disorders as the result of their stimulation of $\mathrm{Na}^{-\mathrm{Cl}^{-}}$, and colonic fluid absorption (Ruppin et al. 1980; Bowling et al. 1993). In fact, prolonged lack of SCFA probably plays an important role in $\mathrm{Na}$ malabsorption in the defunctionalized colon (Roediger et al. 1986). The removal of anions for more than $48 \mathrm{~h}$ converts the colonic mucosa from an absorptive to a secretory state (Roediger, 1992). The colonic secretion of water and electrolytes induced by the osmotic load of enteral feeding may be inhibited in healthy human volunteers by caecal infusion of SCFA mixtures in physiological concentrations (mmol/l; acetate 50, propionate 20, butyrate 20; Bowling et al. 1993).

\section{Possible mechanisms for the effects of short-chain fatty acids on fluid and electrolytes}

The mechanisms by which SCFA exert the aforementioned effects on fluid and electrolyte fluxes are not fully understood, but are thought to be dependent, at least in part, on $\mathrm{CO}_{2}$ generation from the oxidation of butyrate (Roediger, 1982). Of significance are the findings that butyrate is an important energy source and the preferred fuel for the colonic epithelium (Roediger, 1982; Butler et al. 1990). Other mechanisms probably include the butyrate-induced up-regulation of $\mathrm{Na}^{+}-\mathrm{H}^{+}$transport by inducing the 
transcription of mRNA for the $\mathrm{Na}^{+}-\mathrm{H}^{+}$exchanger (Bishop et al. 1992). Also, the induction of other key genes encoding for membrane ATPase ion exchangers may be involved. For example, induction of normal colonocytes by sodium butyrate resulted in a 2 -fold increase in the amount of mRNA expression for the gene encoding the $\mathrm{Na}^{+} / \mathrm{K}^{+}$-ATPase (EC 3.6.1.37) $\alpha$-subunit (Chehab et al. 1987). Hormonal, paracrine and autocrine factors may also play a role. In isolated rabbit distal colon, $n$-butyrate (10 $\mathrm{mM}$ ) causes a stepwise concentration-dependent increase in peptide YY (PYY). PYY inhibits gastric acid and pepsin secretion, and increases gastric emptying and the mouth-to-caecum transit time in human subjects (Adrian et al. 1985).

\section{METABOLISM}

Several studies have shown that SCFA are the preferred fuel for colonocytes (Cummings, 1981; Roediger, 1982; Engelhardt \& Rechkemmer, 1983; McNeil, 1984; Marty \& Vernay, 1984; Awad et al. 1990; Topping et al. 1993). The preference of colonocytes for butyrate as an energy substrate appears to be a tissue-specific phenomenon that is greatest in the rectum and distal colon and less pronounced in the caecum (Windmueller \& Spaeth, 1978; Roediger, 1982). This is interesting, in the light of the predominant anatomical distribution of colon cancer in the distal colon and rectum.

Normal colonocytes rapidly metabolize $n$-butyrate to $\mathrm{CO}_{2}$ and ketones (Roediger, 1980a). In vitro, normal rat colonoctyes utilize SCFA in the following order of preference: butyrate $>$ acetate $>$ propionate (Awad et al. 1990). It has been postulated that the shift from aerobic to anaerobic metabolism that takes place with neoplastic transformation might lead to the inability to oxidize $n$-butyrate (Jass, 1985). The resulting accumulation of butyrate in the cytoplasm of the neoplastic colonocyte plus altered affinity of certain mutated proteins may be the cause of increased sensitivity to butyrate and the paradoxical effect of butyrate on neoplastic $v$. normal cells.

\section{EFFECTS ON COLONIC MOTILITY}

An in vitro study using isolated rat colon examined the contractile effect of SCFA on proximal, middle, and distal segments of the colon. Butyrate effectively stimulated colon contraction at $0.1 \mathrm{~mm}$. The data suggest that butyrate may stimulate colonic contractions via an enteric reflex involving local sensory and cholinergic nerves (Yajima, 1985). The middle and distal colon showed a stimulatory effect of butyrate on contractile response. However, the proximal colon lacked any contractile response to either butyrate or other SCFA. The data suggest that butyrate is probably one of the important physiological lumen stimuli regulating colonic motility.

\section{EFFECTS ON COLONIC BLOOD FLOW}

SCFA infused into autoperfused dog colon in physiological concentrations induce a $24 \%$ increase in colonic blood flow (Kvietys \& Granger, 1981). Dietary manipulations that increase caecal SCFA concentrations lead to an increase in caecal blood flow in rats (Demigné \& Rémésy, 1985). Acetate is the primary cause of these blood flow effects in the dog model. It is postulated that a direct vasodilatory effect of SCFA may mediate this stimulation of blood flow (Rombeau et al. 1990). 


\section{EFFECTS ON COLONIC ANASTOMOTIC HEALING}

Intralumen infusion of SCFA mixture ( $\mathrm{mmol} / 1$; acetate 75 , propionate 35 , butyrate 20 ) in rats significantly increases colonic anastomotic strength (Rolandelli et al. 1986). This SCFA-mediated enhancement of colonic anastomosis healing is thought to be the result of increased mucosal proliferation (Sakata \& Engelhardt, 1983) and stimulation of colonic blood flow with enhanced uptake of $\mathrm{O}_{2}$ (Kvietys \& Granger, 1981).

\section{IMPLICATIONS FOR ULCERATIVE COLITIS}

Studies suggest that the inhibition of fatty acid oxidation in ulcerative colitis may be of pathogenic importance (Butzer et al. 1995). Details of the proposed pathogenic model for ulcerative colitis and the relevance for butyrate have been reviewed by Gibson \& Pavli (1992). Lack of SCFA in the colonic lumen leads to a form of 'nutritional colitis' (Roediger, 1980 b). In fact, decreased faecal concentrations of SCFA are noted in patients with ulcerative colitis, but not in those with Crohn's colitis (Vernay, 1987). The distal colonic epithelium in patients with ulcerative colitis exhibits an impaired ability to oxidize butyrate in vitro (Roediger, 1980b) and in vivo (Roediger et al. 1984). This evidence suggests that colonic epithelium in ulcerative colitis does not fully compensate for its energy deficiency through use of alternative substrates (Kameyama et al. 1984). Histopathologically, the lesions of diversion colitis and ulcerative colitis are indistinguishable (Glotzer et al. 1981). The chemically-induced inhibition of fatty acid oxidation in experimental animals produces mucosal inflammation very similar to that of ulcerative colitis (Glotzer et al. 1981). The predominant dependence of the distal colon on butyrate as its source of energy may be the explanation for the characteristic distribution of ulcerative colitis (Roediger, 1980b). Butyrate enemas (100 mmol/l) were used to treat ten patients with ulcerative colitis in a placebo-controlled single-lined randomized trial (Scheppach et al. 1992b). Findings from this study support the view that butyrate deficiency may play a role in the pathogenesis of distal ulcerative colitis and that butyrate irrigation is beneficial in the treatment of this condition. Study variables in this 2-week study included stool frequency, discharge of blood per rectum, endoscopic score, histological degree of inflammation and upper crypt labelling index, all of which were significantly reduced in patients treated with the butyrate enemas. The control of fatty acid oxidation probably plays an essential role in the development and therapy of active ulcerative colitis (Roediger et al. 1986). In an in vitro study of human colonic epithelial cells from patients with ulcerative colitis incubated with butyrate, there was a significant increase in protein synthesis (Frankel et al. 1994). The authors postulated that the therapeutic effects of butyrate in patients with ulcerative colitis may be due to its use as a metabolic fuel to increase protein production and, thus, promote healing (Frankel et al. 1994).

\section{IMPLICATIONS FOR DIVERSION COLITIS}

SCFA deficiency induced by diverting the faecal stream usually results in the development of diversion colitis. This colitis may be reversed by the instillation of butyrate and other SCFA into the diverted colon (Harig et al. 1989). Therefore, it seems that SCFA are essential in maintaining the integrity of the colonic mucosa. Four patients with diversion colitis were treated with colonic irrigations of SCFA mixtures (mmol/l; acetate 
60 , propionate 30 , butyrate 40 ) for $2-3$ weeks. This therapy resulted in macroscopic and histological resolution of inflammation (Harig et al. 1989). However, in a prospective 2-week double-blind study using rectal enemas of SCFA (mmol/1; acetate 60 , propionate 30 , butyrate 40 ) twice daily for $14 \mathrm{~d}$ in fourteen patients, there was no significant endoscopic and histological improvement (Guillmot et al. 1991). The authors concluded that the heterogeneity of the bacterial population in different types of excluded colon or inadequate total amount of SCFA infusate may have accounted for these negative findings. The aetiology of diversion may be another reason for conflicting results.

\section{IMPLICATIONS FOR COLON CANCER}

Increased ingestion of fibre-rich diets is associated with a low risk of colon cancer (Jacobs, 1986; McIntyre et al. 1993). Human epidemiological studies indicate an inverse correlation between fibre consumption and colon-cancer rates (Jacobs, 1986). Statistical analysis of thirteen case-control studies summarizing data records for 5287 subjects with colon cancer and 10470 control subjects were pooled for analysis of the relationship between dietary fibre intake and colo-rectal cancer risk (Howe et al. 1992). An inverse association was seen in twelve of the thirteen studies, thus providing substantive evidence that intake of fibre-rich foods is associated with a decrease in colo-rectal cancer risk. If causality is assumed, $31 \%$ of all colo-rectal cancers could be prevented by an average increase in fibre intake of about $13 \mathrm{~g} / \mathrm{d}$ (Howe et al. 1992).

Important factors that have been emphasized in the literature include: the carcinogenic effects of bile acids, high colon lumen $\mathrm{pH}$, and the protective role of SCFA, particularly butyrate (Jacobs, 1988; Van Munster \& Nagengast, 1993). In vivo rat studies demonstrate that dietary fibre and fat mediate cell proliferation of the colon in an interactive, site-specific manner (Lee et al. 1993). In vivo human studies indicate that a short-term increase in dietary fat and decrease in dietary fibre does not increase colonocyte proliferation rate, thus suggesting that long-term rather than acute exposure might be of significance in human subjects (Gregoire et al. 1991).

The products of fibre fermentation within the colonic lumen are probably key factors in protection against colonic carcinogenesis (Van Munster \& Nagengast, 1993), although there may be many other factors. Butyrate is one of the most significant products of fermentation since it exhibits anti-neoplastic properties both in vitro and in vivo (Kim et al. 1980; Tsao et al. 1982; Dexter et al. 1984; Whitehead et al. 1986; Czerniak et al. 1987; Otaka et al. 1989; Young, 1990; Gibson \& Pavli, 1992; Scheppach et al. 1992a; Souleimani \& Asselin, 1992; Bartram et al. 1993, 1995; McIntyre et al. 1993; Van Munster \& Nagengast, 1993; Scheppach, 1994). Patients with adenomatous polyps or colon cancer have lower rates of butyrate fermentation than normal subjects (Weaver et al. 1988), but whether altered levels of butyrate are merely an associated or causative factor in colon cancer remains in question (Bradburn et al. 1993).

The experimental data using butyrate as a direct dietary supplement either to treat or prevent colonic neoplasia has been discouraging. An in vivo study using 10-20 g sodium butyrate/l in the drinking water of rats failed to demonstrate any anti-neoplastic effect in 1,2-dimethylhydrazine-induced rat intestinal neoplasia (Freeman, 1986). In another in vivo study, butyrate was introduced in the diet of rats treated with the carcinogen azoxymethane. In this work, butyrate also failed to protect against the development of aberrant crypts, which was the anti-neoplastic end-point examined (Wargovich et al. 
1992). These results should be interpreted with caution since orally-ingested butyrate is almost completely absorbed in the small intestine before reaching the colon (Young \& Gibson, 1994).

However, the in vivo effects of diets rich in insoluble fibre as a substrate precursor to increase colonic butyrate levels are promising. Wheat-bran-rich diets were studied in rats throughout periods of tumour initiation and promotion (Young, 1990). This study demonstrated that wheat-bran-rich diets protected against tumour growth. Other studies which examined diets rich in soluble fibre such as guar gum or pectin (which are known not to increase the colonic butyrate concentrations), failed to demonstrate a protective effect against tumourigenesis (McIntyre et al. 1991).

In a rat colon-cancer model, increased faecal levels of butyrate (an index of distal colon butyrate levels) are induced by dietary manipulations (wheat-bran-rich diets) and are associated with a significant decrease in tumour size in vivo (McIntyre et al. 1993). In human subjects, the ingestion of processed wheat bran in patients with familial adenomatous polyposis decreases the incidence of adenoma formation in the remaining rectum within 9 months of follow up (DeCosse et al. 1989).

It is not possible to draw definitive conclusions regarding butyrate effects from experiments using diets enriched with wheat fibre since other aspects of the diet may be confounding variables; however, the data are encouraging and certainly lend validity to the in vitro findings on the anti-neoplastic effects of butyrate.

\section{BUTYRATE EFFECTS ON PROLIFERATION: NORMAL $v$. NEOPLASTIC COLONOCYTES}

Although butyrate decreases proliferation of neoplastic colonoctyes in vitro (Kim et al. 1980; Tsao et al. 1982; Whitehead et al. 1986; Czerniak et al. 1987; Colony, 1989; Awad et al. 1991; Barnard \& Warwick, 1992; Souleimani \& Asselin, 1992), and in vivo (DeCosse et al. 1989; McIntyre et al. 1993), it increases proliferation of normal colonic epithelium in vitro (Gibson \& Pavli, 1992) and in vivo (Sakata, 1984, 1987; Kripke et al. 1989; see Table 1).

\section{Trophic effects on normal colonic epithelium}

Ample evidence exists to show that butyrate in the colonic lumen plays an important role in mucosal growth and epithelial proliferation. A reduction in lumen butyrate by

Table 1. The paradoxical effects of butyrate on cell proliferation and differentiation of normal and neoplastic colonic epithelial cells (Reproduced with permission from Young \& Gibson, 1995)

\begin{tabular}{|c|c|c|c|c|}
\hline & \multicolumn{4}{|c|}{ Effect of butyrate } \\
\hline & \multicolumn{2}{|c|}{ Normal cells } & \multicolumn{2}{|c|}{ Cancer cells } \\
\hline & In vitro & In vivo & In vitro & In vivo \\
\hline Cell proliferation & $\begin{array}{l}\text { No change/ } \\
\text { increased? }\end{array}$ & Increased & Reduced & Probably reduced \\
\hline Differentiation & Suppressed & No change & Induced & Unknown \\
\hline
\end{tabular}


decreased delivery of fermentable substrate to the large intestine induces colonic mucosal atrophy (Janne et al. 1977; Goodlad \& Write, 1983; Saka, 1988). Subsequent instillation of SCFA into the colonic lumen induces mucosal regeneration as shown by increased mucosal weight and DNA content, increased crypt length, and increased mitotic index (Sakata, 1984; Kripke et al. 1989). Of the three major SCFA, these effects on colonic mucosal proliferation are thought to be mostly due to butyrate (Sakata, 1987; Kripke et al. 1989). In an in vivo rat model, both intravenous and intracolonic infusions of SCFA significantly reduce the mucosal atrophy associated with long-term total parenteral nutrition (TPN; Koruda et al. 1990). Another in vivo study using rats maintained on TPN shows that infusion of a SCFA mixture (acetate-propionatebutyrate; $60: 25: 15$ by vol.) into the proximal colon significantly increases colonic mucosal height and colonic mucosal DNA (Freidel \& Levine, 1992). A diet rich in wheat bran fed to rats significantly increases the concentration of butyrate throughout the colon (Lupton $\&$ Kurtz, 1993). The colonic lumen concentration of butyrate had the strongest positive correlation to indices of cell proliferation. An in vitro study using human colonic mucosa demonstrated that propionate and, more significantly, butyrate $(10 \mathrm{mmol} / \mathrm{l})$ are lumen trophic factors for the human caecal epithelium (Scheppach et al. 1992a).

The mechanisms by which butyrate enhances normal colonic mucosal proliferation are not well understood. There is evidence that butyrate exerts an indirect systemic effect since colonic lumen SCFA mixtures stimulate proliferation not only in colonic mucosa, but also in unexposed adjacent colonic epithelium, ileum and jejunum (Sakata \& Engelhardt, 1983; Sakata, 1987; Kripke et al. 1989; Frankel et al. 1994). Infusion of SCFA into the colonic lumen stimulates growth in unperfused isolated denervated loops of jejunum in rats (Sakata, 1987). However, butyrate probably also has a direct effect on proliferation, since it stimulates epithelial proliferation in short-term organ culture of human colonic mucosa in the absence of circulating or neural factors (Scheppach et al. 1992a). A more detailed discussion of the possible mechanisms of action for butyrate on proliferation will be discussed later (see p. 64).

\section{Inhibitory effect on neoplastic colonocyte growth}

Butyrate inhibits DNA synthesis and arrests the growth of neoplastic colonocytes in the G1 phase of the cell cycle (Toscani et al. 1988). These effects are shown in multiple cultured tumour cell lines (Young \& Gibson, 1994). The concentrations used to produce these effects are not toxic to cells. RNA and protein synthesis is minimal and cells remain viable and functional. Butyrate inhibits the proliferation of LIM-1215 cultured colon cancer cells at concentrations of $1-10 \mathrm{mmol} / \mathrm{l}$ (Whitehead et al. 1986). Butyrate at a concentration of $1 \mathrm{mmol} / \mathrm{l}$ increases cell doubling time from 26 to $72 \mathrm{~h}$ and decreases the cloning efficiency from 1.1 to $0.05 \%$ (Whitehead et al. 1986). In this study, acetate and propionate showed only minimal effects of proliferation. Similar inhibition of proliferation is noted in several other in vitro studies using colo-rectal cancer cell lines such as SW480, SW620, HRT-18, HT-29, CaCo-2 and LS180 (Kim et al. 1980; Tsao et al. 1982; Whitehead et al. 1986; Czerniak et al. 1987; Colony, 1989; Barnard \& Warwick, 1992; Souleimani \& Asselin, 1992). Anchor-dependent growth is inhibited by butyrate at a concentration of $2 \mathrm{mmol} / \mathrm{l}$ in the HRT-18 cell line, under conditions which do not affect cell viability (Tsao et al. 1982). Withdrawal of butyrate from the culture medium rapidly 
reverses the effects on proliferation. Higher concentrations $(5 \mathrm{mmol} / \mathrm{l})$ lead to increases in cell toxicity and decreases in cell viability (Tsao et al. 1982).

\section{Inhibition of pre-malignant crypt surface hyperproliferation}

Patients at risk for increased colon cancer (e.g. familial polyposis coli and Gardner's Syndrome) have pre-malignant colonocyte proliferation with a shift of the proliferative zone from the crypt base to the upper $40 \%$ of the crypt (Lipkin, 1988; Deschner et al. 1990). In endoscopically-obtained biopsies from normal human mucosa, incubation with butyrate significantly increases colonic crypt cell proliferation at the physiological concentration of $10 \mathrm{mmol} / \mathrm{l}$. Butyrate-induced proliferation (observed only in the basal $60 \%$ of the crypt) is considered to be the zone of physiological crypt cell proliferation and not a pre-malignant event (Scheppach et al. 1992a). In follow-up in vitro studies also using normal human colonic mucosa, deoxycholate-induced crypt surface (pre-malignant) hyperproliferation was inhibited by co-incubation with butyrate (Bartram et al. 1993).

\section{BUTYRATE EFFECTS ON DIFFERENTIATION: NORMAL $v$. NEOPLASTIC COLONOCYTES}

While butyrate induces differentiation of neoplastic colonocytes in vitro (Kim et al. 1980; Dexter et al. 1984; Whitehead et al. 1986; Awad et al. 1991; Barnard \& Warwick, 1992) and in vivo (Otaka et al. 1989), it decreases, or has no significant effect on, the expression of differentiation markers in normal colonocytes in vitro (Gibson \& Pavli, 1992) and in vivo (Young, 1991; Young \& Gibson, 1995; see Table 1).

It has been suggested that differentiation is a state in which a cell is locked in the G1 phase of the cell cycle where components necessary for mature cellular function are expressed in an orderly manner (Higgins, 1989). Neoplasia is thought to arise when a series of defects (usually at the genomic level) lead to the ability of the cell to escape the state of terminal differentiation (Kim et al. 1980). Butyrate has generated great interest in its ability to lock colonocytes in the G1 phase and induce a morphologically differentiated phenotype (Whitehead et al. 1986; Young \& Gibson, 1994).

\section{Induction of differentiation markers in neoplastic colonocytes}

In vitro modulation of the expression of brush-border hydrolases. Brush-bordermembrane enzymes such as alkaline phosphatase (EC 3.1.3.1) are considered markers of differentiation, and their expression decreases with neoplastic transformation (Bell \& Williams, 1979; Young et al. 1992). Evidence obtained from a study of brush-border hydrolases in normal and neoplastic human colonic epithelium biopsies demonstrate a low expression of brush-border hydrolases in adenomas, which suggests a block in the differentiation process early in colo-rectal carcinogenesis (Young et al. 1992). Patchy re-expression of brush-border hydrolases as well as a loss of cellular polarity is noted in the carcinomas, suggesting a subsequent derepression of gene expression for these enzymes. A specific form of alkaline phosphatase (human placental-like alkaline phosphatase (PLAP)) is induced by sodium butyrate in several colo-rectal adenocarcinoma cell lines in culture (Kim et al. 1980; Herz et al. 1981; Morita et al. 1982; Tsao et al. 1982; Ito \& Chou, 1984; Chung et al. 1985). 
Studies with Lim 1215 cultured colon cancer cells and butyrate at concentrations of $1 \mathrm{mmol} / \mathrm{l}$ demonstrate a $600 \%$ increase in the activity of alkaline phosphatase. Acetate and propionate have similar but less marked effects. Both proliferative effects and effects on alkaline phosphatase activity occur at the same time in culture, suggesting a possible link between differentiating and anti-proliferative effects (Whitehead et al. 1986). Associated with these effects on proliferation and differentiation are phenotypic changes such as higher cytoplasm:nucleus values. In HT-29 cells, incubation with butyrate rapidly induces 'enterocytic-like' differentiation and growth inhibition while concomitantly inducing alkaline phosphastase mRNA (Barnard \& Warwick, 1992).

The in vitro effects of butyrate on brush-border-membrane hydrolases were studied using fourteen different colon-cancer cell lines (Chung et al. 1985). Butyrate increased the activity of alkaline phosphatase in ten of the fourteen cell lines examined, in magnitudes ranging from 2- to 123 -fold increases. This effect on alkaline phosphatase activity is inhibited by the addition of cycloheximide (in the HRT-18 cell line), thus providing evidence that this increase is secondary to new protein synthesis rather than gradual protein breakdown (Tsao et al. 1982). The investigators reported a significant correlation between induction of alkaline phosphatase activity and the degree of morphological differentiation.

In vivo modulation of the expression of brush-border hydrolases. Using encapsulated liposomes that are covalently linked to an anti-Le ${ }^{\mathrm{X}}$ monoclonal antibody (Otaka et al. 1989), selective in vivo delivery of butyrate was accomplished in nude mice bearing human colon adenocarcinoma tumours. Increases in membrane-bound alkaline phosphatase and $\gamma$-glutamyl transpeptidase (EC 2.3.2.2) were noted, indicating the occurrence of in vivo butyrate-induced differentiation of neoplastic colonocytes. However, when large-bowel lumen butyrate was experimentally increased in rats by feeding a wheat-bran-rich diet, no significant in vivo effects were documented on the expression of the brush-border hydrolases, alkaline phosphatase and dipeptidyl peptidase IV ( $E C$ 3.4.14.5), by the normal colonic mucosa (Young, 1991).

\section{Contrasting effects on normal colonocytes}

When cells harvested from microscopically normal human colonic mucosa (obtained from cancer-bearing colon) are cultured in vitro, incubation with butyrate does not show a reduction in the rates of energy-consuming processes such as DNA, protein, and glycoprotein synthesis. Furthermore, total DNA content is not altered (Gibson et al. 1991). Moreover, the expression of differentiation markers significantly decreases in these cells after a $24 \mathrm{~h}$ incubation with butyrate, suggesting that it does not enhance, but may suppress, differentiation of normal colonocytes (Gibson et al. 1991). This paradoxical effect of butyrate on normal and neoplastic colonocytes and their differentiation is unlikely to be artifactual (Young \& Gibson, 1994).

\section{BUTYRATE-INDUCED MODULATION OF GENE EXPRESSION}

\section{Multi-stage colo-rectal carcinogenesis}

The multi-stage process of carcinogenesis in the aetiology of colon cancer (Fearon \& Vogelstein, 1990) is now well accepted. There seems to be a step-like progression from 
normal epithelium, to hyperproliferative epithelium, to aberrant crypts, to various stages of dysplasia (seen in adenomas), to pre-invasive and finally, to invasive and metastatic carcinomas (Willson, 1989; Fearon \& Vogelstein, 1990). Data at this time suggest that this multi-step process results from an accumulation of genetic alterations (Fearon \& Vogelstein, 1990). The known series of genetic alterations in the development of human colo-rectal carcinoma include the familial adenomatous polyposis coli-mutated in colon cancer locus (FAP/MCC) on chromosome 5, the DCC (deleted in colo-rectal cancer) gene on chromosome 18, and the p53 gene on chromosome 17 (Young \& Gibson, 1994). A mutation of the ras proto-oncogene is thought to be aetiologically important as well. Mutations in the FAP/MCC gene may be inherited, whereas the other previously mentioned genetic events are acquired in random order (Young \& Gibson, 1994). These genetic changes, whether acquired or inherited, express themselves as disordered protein synthesis, and thus alter cellular growth and differentiation. The p53 gene is commonly involved in colo-rectal carcinoma, but not adenomas (Fearon \& Vogelstein, 1990), and may be important in normal cells as a tumour suppressor gene. A deletion of the allelic pair, or a mutation that produces an oncogenic form, may provide a selective growth advantage or the ability to invade (Fearon \& Vogelstein, 1990). In intermediate and late adenomas, a mutation of the ras proto-oncogene is a common finding. It is possible that this mutation may initiate events in some colo-rectal carcinomas, or may be responsible for increasing dysplasia in some adenomas (Young \& Gibson, 1994). Other oncogenes are implicated in colo-rectal carcinogenesis such as the amplification and gene rearrangements of c-myc, c-myb, src, and the trk (Foss et al. 1989; Fearon \& Vogelstein, 1990).

The effects of butyrate on the expression of FAP/MCC, DCC, and p53 protooncogenes in colonocytes are not known, but inhibition in the expression of c-ras, $\mathrm{N}$-ras, $c-s r c, c-m y c$, and c-myb genes have been reported in several colo-rectal cell lines in vitro (Young \& Gibson, 1994). Table 2 summarizes the major effects of butyrate on key molecular events relevant to large-bowel neoplasia (Young \& Gibson, 1995).

Table 2. Summary of effects of butyrate on molecular events relevant to large-bowel neoplasia (Reproduced with permission from Young \& Gibson, 1995)

\begin{tabular}{lcc}
\hline \hline Gene & Chromosome & Effect of butyrate \\
\hline FAP/MCC & $5 \mathrm{q}$ & Unknown \\
p53 & $17 \mathrm{p}$ & Unknown \\
DCC & $18 \mathrm{q}$ & Unknown \\
c-ras & $12 \mathrm{p}$ & p21 inhibited \\
& & (HT29 cells) \\
c-src & & pp60, p56 inhibited \\
& & (SW620 cells) \\
c-myc & & Inhibited \\
L and B and K alkaline & Activated or induced \\
phosphatase $(E C$ 3.1.3.1) & $1 \mathrm{p}$ & (many cell lines) \\
\hline \hline
\end{tabular}

$\mathrm{L}$ and $\mathrm{B}$ and $\mathrm{K}$ alkaline phosphatase, liver, bone and kidney alkaline phosphatase, the form expressed in colon. 


\section{POSSIBLE MECHANISM OF ACTION FOR BUTYRATE EFFECTS ON COLONOCYTE GROWTH AND DIFFERENTIATION}

Butyrate modulates the transcriptional expression of multiple genes (Toribara et al. 1989; Kruh et al. 1995). Butyrate has several effects on nuclear proteins through which it could modify gene expression. These effects include: (1) hyperacetylation of core histones through the inhibition of histone deacetylase (Boffa et al. 1978), (2) selective inhibition of the phosphorylation of histones H1 and H2 (Boffa et al. 1981; Kruh, 1982), (3) selective increase in the phosphorylation of $\mathrm{H} 3$ histone (Parker et al. 1985), and (4) hypermethylation of cytosine residues in DNA (Boffa et al. 1981; Parker et al. 1985; Kruh et al. 1994). Butyrate also enhances the acetylation and phosphorylation of non-histone proteins and increases ADP ribosylation (Rastl \& Swetly, 1978; Cousenes et al. 1979; Christman et al. 1980; Boffa et al. 1981; Kruh, 1982; Kruh et al. 1994). The significance of these varied molecular effects is not well understood and differs among the multiple in vitro cell lines studied. In general, histone hyperacetylation is associated with increased gene expression (Reeves \& Dserjesi, 1979) and increased DNAase I (EC 3.1.21.1) sensitivity (Vidali et al. 1978). Hypermethylation of cytosine residues in DNA is associated with decreased gene expression. H1 histone phosphorylation is associated with progression of the cells in the cell cycle (Boffa et al. 1981). The induction and inhibition of gene expression produced by DNA methylation are thought to be non-specific. However, butyrate can also specifically modulate gene expression. For example, in the human colon adenocarcinoma cell line $\mathrm{CaCo}-2$, butyrate causes a direct activation of the PLAP promoter (Deng et al. 1992). It is suggested that butyrate acts as a cofactor of regulatory transcription proteins in the nucleus which are directly involved in gene expression (Kruh et al. 1994; see Fig. 2).

Alternatively, butyrate may act at the membrane-cytoplasmic interface by interacting with the G-proteins which are key components of the signal transduction pathway in cellular growth and differentiation (see Fig. 2). Mutated G-proteins are the products of activated ras oncogenes which are thought to play a role in early colo-rectal carcinogenesis (Bos et al. 1987; Vogelstein et al. 1988). Butyrate suppresses the transforming activity of an activated $\mathrm{N}$-ras oncogene in cultured human colon carcinoma cells (Stoddart et al. 1989). Binding of the G-protein to SCFA, mevalonate (or one of its metabolic intermediates), is required for membrane translocation and subsequent ras protein activation in yeast and humans (Willumsen et al. 1984; Schafer et al. 1989). Colon cancer cells in vivo have been shown to switch from principally aerobic to anaerobic metabolism (Jass, 1985). We postulate that in the neoplastic colonocyte, butyrate (which may accumulate as a result of impaired oxidation) may compete for mevalonate (or a mevalonate intermediate)-binding and, thus, interfere with the process of membrane translocation and activation of the mutated ras protein. Studies are ongoing to investigate this hypothesis (see Fig. 2).

\section{MEDIUM-CHAIN TRIACYLGLYCEROLS}

\section{Medium-chain triacylglycerols and long-chain triacylglycerols (LCT)}

Recently, the use of MCT as a parenteral high-density energy source has been investigated. MCT are obtained from hydrolysed coconut oil and consist of a mixture of $(\mathrm{mol} / 100 \mathrm{~mol}): \mathrm{C}_{6: 0}<1, \mathrm{C}_{8: 0} 65-75, \mathrm{C}_{10: 0} 25-35, \mathrm{C}_{12: 0}<1$; Wan et al. (1988). MCT were 


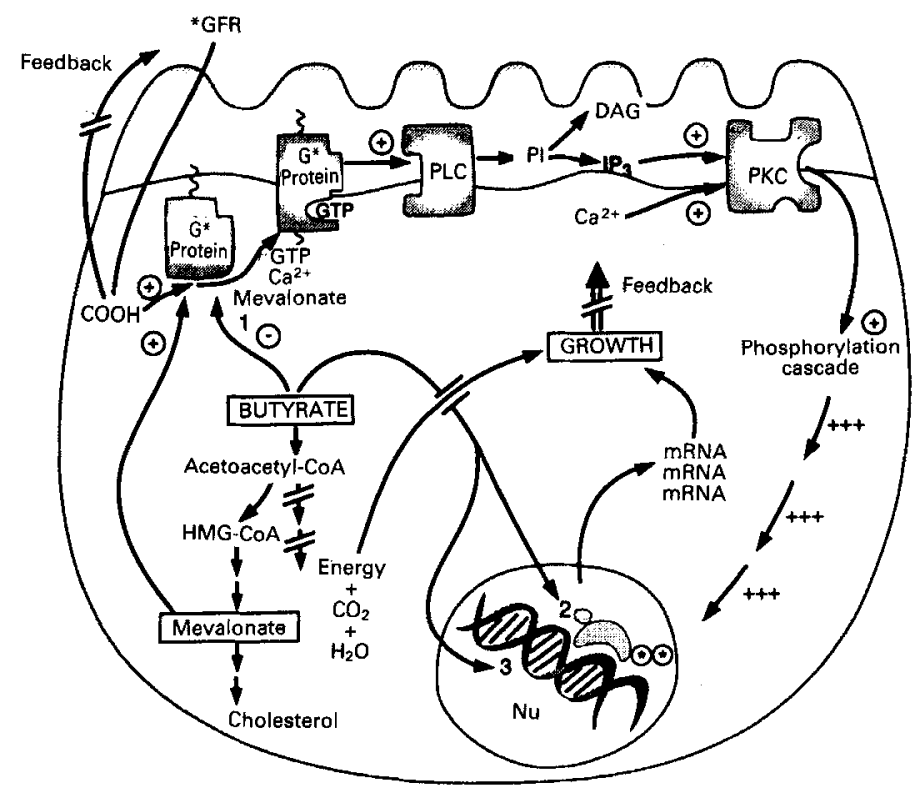

Fig. 2. Speculative mechanisms for butyrate-induced growth inhibition in neoplastic colonocytes. Evidence suggests that $\mathrm{G}$ proteins require binding to mevalonate or a mevalonate intermediate for translocation into the membrane and subsequent activation (Schafer et al. 1989). The activated G protein then stimulates the activity of protein kinase $\mathrm{C}(\mathrm{PKC})$ via the activation of phospholipase $\mathrm{C}$ (EC 3.1.4.3; PLC). The cascade of enzymic phosphorylations resulting from the activation of $\mathrm{PKC}$ leads to a signal for growth. Activated ras oncogenes encode for mutated $G$ proteins $\left(G^{*}\right)$. Butyrate has been shown to inhibit the transforming action of an activated human ras oncogene (Stoddart et al. 1989). With a switch to anaerobic metabolism in the neoplastic colonocyte, butyrate may accumulate in the cytoplasm (Jass, 1985). (1) We speculate that butyrate may then compete with mevalonate (or a mevalonate intermediate) in the binding to $\mathrm{G}^{*}$, but the butyrate- $\mathrm{G}^{*}$ combination results in an active form of the $\mathrm{G}^{*}$ protein. Alternative mechanisms have been proposed (Kruh et al. 1994) that include: (2) butyrate may specifically modulate gene expression as a cofactor to the transcription proteins, and (3) non-specific modulation of gene expression via chromatin changes induced by DNA methylation and histone acetylation. GFR, growth factor receptor; HMG-CoA, hydroxymethylglutaryl$\mathrm{CoA}$; PI, phosphatidyl inositol; PI3, inositol triphosphate; DAG, diacylglycerol; $\mathrm{Nu}$, nucleus.

postulated to be a more-efficient energy source than LCT because of their non-carnitinedependent transport into the mitochondria, higher plasma clearance, and higher oxidation rate (Bohmer et al. 1974; Bach \& Babayan, 1982). Also, animal studies demonstrated improved N-sparing effects with MCT (Maiz et al. 1984b; Mok et al. 1984; Sandberg et al. 1985; Dawes et al. 1986; Magnussen et al. 1986), and less accumulation in the reticulo-endothelial system during long-term treatment (Hamawy et al. 1985b; Sobrado et al. 1985). However, large doses of pure MCT emulsions are toxic, lack the important essential polyunsaturated fatty acids, and induce metabolic acidosis. In contrast, intravenous LCT emulsions are generally well-tolerated and safe.

LCT are made from soyabean or safflower vegetable oils, contain fatty acyl chains of $\mathrm{C}_{16}-\mathrm{C}_{18}$ in length, and represent the standard of care in parenterally-administered fat emulsions. Lipid emulsions composed of LCT have been in use for many years in parenteral nutrition to provide a concentrated form of energy and essential fatty acids while reducing the requirement for high glucose loads. 


\section{Metabolism of medium-chain triacylglycerols v. long-chain triacylglycerols}

LCT-derived fatty acids must use the carnitine transport pathway to enter the mitochondria for oxidation (Mitchell, 1978). Researchers have suggested that in clinically-stressed situations, the carnitine transfer system eventually becomes saturated, leading to decreased efficiency of LCT metabolism (Bohmer et al. 1974; Wan et al. 1988). In these patients, LCT are not completely oxidized, and some long-chain fatty acids are re-esterified to triacylglycerols in the liver (Goodenough \& Wolfe, 1984). In contrast, MCT undergo $\beta$-oxidation without requiring the presence of carnitine (Bremer, 1980; Bach \& Babayan, 1982). Moreover, the physical properties of MCT favour normal hepatic and splenic reticulo-endothelial system function (Mascioli et al. 1988).

MCT have been studied in varied types of animal models. MCT infusion in burned animals was noted to reduce pulmonary sequestration of bacteria (Sobrado et al. 1985). In rats receiving TPN with MCT emulsions for cancer cachexia there is decreased tumour growth and lung metastases (Bartlet et al. 1992).

Human studies have shown that MCT are metabolized faster than LCT (Yeh et al. 1978; Wolfram et al. 1985; Bach et al. 1988; Deckelbaum et al. 1990), thereby providing a readily-available energy burst. The $\beta$-oxidation of MCT yields $C_{2}$ units and energy (Sailer \& Berg, 1974). MCT can overwhelm the biochemical pathway which allows them to enter into the Krebs cycle and then be metabolized by an alternative pathway to produce ketones (acetoacetate and $\beta$-hydroxybutyrate; Sailer \& Berg, 1974; Yeh \& Zee, 1976; Bach et al. 1977). These ketone bodies are utilized as fuel by peripheral tissues (Guisard \& Debry, 1972; Robinson \& Williamson, 1980; Sailer \& Muller, 1981). Patients stressed by surgery, burns, and shock form ketone bodies within skeletal muscle mass as an alternative form of fuel, thereby reducing proteolysis from branched-chain amino acids (Maiz et al. 1984a; Mok et al. 1984). For these reasons, MCT have been proposed as feasible non-carbohydrate sources of energy which may be useful in severely ill patients, especially those with glucose intolerance. However, in a study of nine healthy male subjects MCT administration led to pronounced ketogenesis without significant improvements in oral glucose tolerance (Weissman et al. 1988). Other human studies have reported more favourable results. In twelve adult patients requiring major abdominal surgery for gastric ulcer, gastric cancer, and colon cancer, TPN with MCT emulsions resulted in improved muscle energy utilization, improved $\mathrm{N}$ balance and less weight loss postoperatively compared with standard LCT emulsions (Jiang et al. 1993).

\section{Absorption: long-chain triacylglycerols $\mathrm{v}$. medium-chain triacylglycerols}

Oral administration of MCT has been useful for many years in the treatment of disorders of lipid absorption (Hashim et al. 1960, 1962). MCT emulsions are hydrolysed efficiently in the lumen of the small intestine under conditions where LCT hydrolysis is impaired, such as in pancreatic insufficiency (see Fig. $3(a$ and $b)$ ). While LCT are entirely absorbed through the lymphatic system, orally-administered MCT are hydrolysed by mucosal lipase (EC 3.1.1.3) and the resulting medium-chain fatty acids (MCFA) are absorbed through the intestinal capillaries. These MCFA bind to albumin and are transported to the liver via the portal venous system (Bach \& Babayan, 1982; Babayan, 1987; Hashim \& Tantibhedyangkul, 1987). Parenterally-administered MCT are hydrolysed by the lipoprotein lipase (EC 3.1.1.34) system within the capillaries and released MCFA bind to albumin and are transported to various tissues for utilization (Sailer \& 
(a)

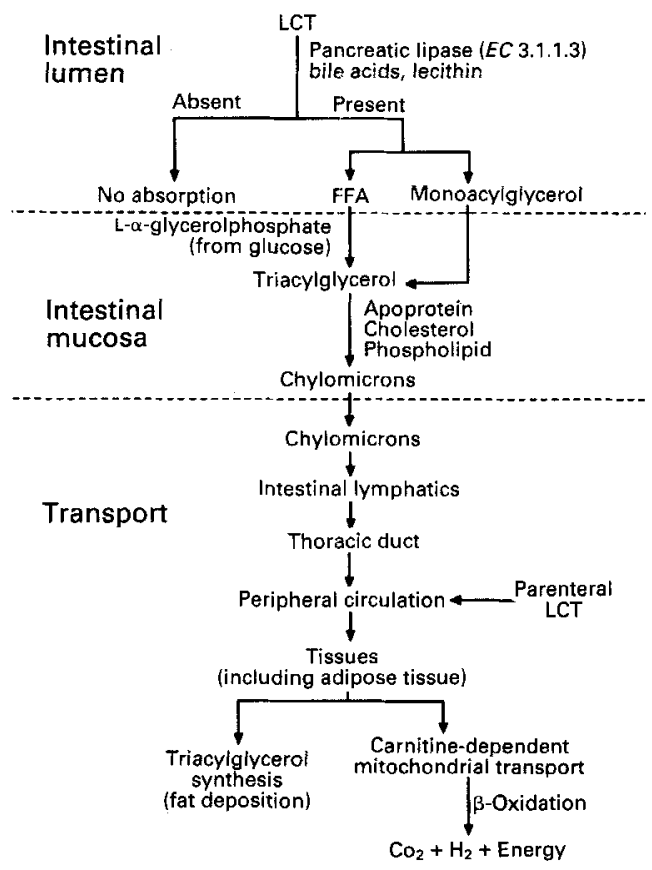

(b)

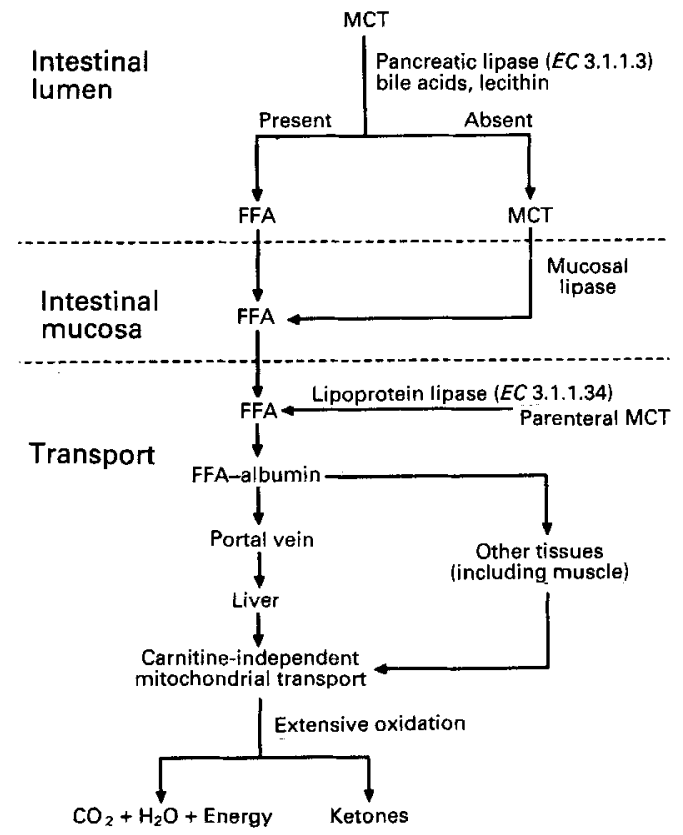

Fig. 3. Digestion, absorption, transport, and metabolism of (a) long-chain triacylglycerols (LCT) and (b) medium-chain triacylglycerols (MCT). FFA, free fatty acid. (Adapted and reproduced with permission from Hashim \& Tantibhedyangkul, 1987.) 
Berg, 1974). Unlike LCT, MCT are rapidly cleared from circulation (Dawes et al. 1986) and their resulting MCFA enter cells at a higher rate than the long-chain fatty acids (Thomson, 1978).

\section{Side effects of parenterally-administered lipids}

Although LCT are generally well-tolerated, they are not free from side effects. Adverse reactions have been reported with rapid infusion rates in excess of $4.2 \mathrm{~kJ} / \mathrm{kg}$ per h (Klein \& Miles, 1994). Adverse effects include impaired immune, pulmonary, hepatic and platelet function (Miles, 1991). In addition, only 30\% of the LCT administered are oxidized whereas the remainder are stored (Lanser \& Saba, 1981; Bennegard et al. 1984). In traumatized animals, excessive administration of LCT may overwhelm the reticulo-endothelial system with resulting hepatomegaly and splenomegaly (Sobrado et al. 1985).

In general, pure MCT emulsions are less well-tolerated than LCT. Adverse effects with parenteral MCT emulsions reported in animals include poor growth and $\mathrm{N}$ balance and increased energy expenditure (Wiley \& Leveille, 1973; Stein et al. 1984; Hill et al. 1989). Some reports have indicated that MCT may not spare protein catabolism as well as LCT (Rodriguez et al. 1986). More importantly, MCT are not well tolerated by patients, and moderate to severe side effects have been reported, such as neurotoxicity (Miles et al. 1991), emesis, somnolence, coma (Miles et al. 1991), narcosis, essential fatty acid deficiency, and ketosis in susceptible diabetic patients (Bach et al. 1974; Gordon \& Duger, 1975). Early enthusiasm for parenteral MCT emulsions was tempered by reports of acute toxicity associated with excess administration. Doses as low as $1.5 \mathrm{~g} / \mathrm{kg}$ body weight per $h$ in dogs resulted in nausea, vomiting, somnolence, and in higher doses, coma and death (Cotter et al. 1987). Increased mortality in septic rats infused with MCT as a component of their TPN has been reported (Stein et al. 1986). Some of these side effects have been attributed to uncoupling of oxidative phosphorylation resulting from the uncontrolled entry of MCFA into the mitochondria when excess MCT are provided (Pressman \& Lardy, 1956; Stein et al. 1984).

MCT-LCT mixtures and structured lipids $(S L)$. It has been proposed that a combination of MCT and LCT may offer advantages over pure LCT or MCT emulsions. This combination could be obtained by either a physical mixture of LCT and MCT, or by re-esterification of LCT and MCT on the backbone of glycerol, otherwise known as SL, or structured triacylglycerols. Active research is currently targeting these areas.

Physical mixing of MCT and LCT emulsions does not alter their subsequent clearance kinetics such that corresponding triacylglycerols are cleared from the blood at rates unaffected by the presence of the other. Similarly, the oxidation rate of MCT and LCT emulsions is unaffected by the presence or absence of other triacylglycerols (Hamawy et al. 1985). Nonetheless, emulsions containing MCT-LCT $(50: 50, \mathrm{v} / \mathrm{v})$ are relatively safe for use in parenteral nutrition, and may provide an alternative fuel that improves protein metabolism (Jiang et al. 1993).

Trans-esterification of MCT with LCT forms new triacylglycerols with intermediate clearance and oxidation rates between MCT and LCT (Babayan, 1987; Ekman et al. 1987). These SL have the benefits of MCT without some of the side effects. In the burned animal model, SL have superior protein-sparing effects over conventional triacylglycerols (Maiz et al. 1984b; DeMichele et al. 1988). These animals have improved 
weight gain, $\mathrm{N}$ balance, liver and muscle protein content and serum albumin synthesis. SL do not increase energy expenditure as MCT emulsions often do (Mok et al. 1984). SL included in TPN of burned rats improves $\mathrm{N}$ balance and hepatic protein synthesis, and decreases leucine oxidation (Maiz et al. 1984b; Mok et al. 1984). SL stimulates muscle protein synthesis in rats after partial hepatectomy (Magnussen et al. 1986). Parenteral SL do not adversely affect the reticulo-endothelial system in burned guinea-pigs (Sobrado et al. 1985). SL improve $\mathrm{N}$ balance and protein loss, decrease hypertriacylglycerolaemia, and prevent fat accumulation in the liver (Bach et al. 1988). These animal studies have shown that SL are more beneficial than either LCT or a physical mixture of LCT and MCT (Maiz et al. 1984b; Mok et al. 1984; Bach et al. 1988; Teo et al. 1989), and lack the side effects of pure MCT emulsions (Moyer et al. 1989).

To date, few human studies with SL have been reported. In patients undergoing elective surgery infusion of SL demonstrated no significant difference in safety or tolerance compared with the clinical standard LCT emulsion, Intralipid ( $200 \mathrm{ml} / 1$; Sandström et al. 1993). The advantages and clinical applications of SL parenteral emulsions in human subjects will probably be an active and fruitful area of future investigations.

\section{CONCLUSIONS AND FUTURE RESEARCH}

SCFA are essential for the normal structure and function of the colonic epithelium, and may have therapeutic potential in certain colonic pathologies such as diversion colitis, ulcerative colitis, and enteral-feeding-induced diarrhoea. Butyrate may be the key byproduct of fibre fermentation that has a role in the prevention and treatment of colon cancer. The many effects of butyrate on the colonocyte probably reflect its ability to both specifically and non-specifically affect genomic expression. Butyrate may also serve as a useful model to delineate the process of colo-rectal carcinogenesis at a molecular level. Future work is needed to evaluate the in vivo importance of maintaining a balance between possible colon carcinogenic substances such as bile acids and possible protective agents such as butyrate, both of which can be modulated by dietary interventions. Further work is needed to delineate the mechanism(s) of action of butyrate and to determine its role in the understanding, prevention, and treatment of colon cancer.

In general, parenteral LCT are effective and well-tolerated. However, adverse effects with rapid infusions of LCT emulsions and the requirement for the carnitine-dependent active transport into the mitochondria for oxidation have led to the search for alternate lipid fuels. MCT have attracted a great deal of attention for their theoretical benefit in conditions associated with carnitine depletion such as sepsis, burns, and multi-organ trauma. With the recognition that pure MCT have adverse side effects, the search continues for the ideal fat emulsion. The design of SL has offered marked advances over pure MCT emulsions. Initial studies with SL are promising. It is likely that SL will not replace, but instead supplement, the available choices in lipid parenteral nutrition.

\section{REFERENCES}

Adrian, T. E., Ferri, G.-L, Bacarese-Hamilton, A. J., Fuessl, H. S., Polak, M. \& Bloom, S. R. (1985). Human distribution and release of a putative new gut hormone peptide YY. Gastroenterology 89, 1070-1077.

Argenzio, R. A., Miller, N. \& Engelhardt, W. v. (1975). Effect of volatile fatty acids on water and ion absorption from the goat colon. American Journal of Physiology 229, 997-1002. 
Argenzio, R. A., Southworth, M., Lowe, J. E. \& Stevens, C. E. (1977). Inter-relationship of Na, $\mathrm{HCO}_{3}$ and volatile fatty acid transport by equine large intestine. American Journal of Physiology 233, E469-E478.

Argenzio, R. A. \& Whipp, S. C. (1979). Inter-relationship of sodium, chloride, bicarbonate and acetate transport by the colon of the pig. Journal of Physiology 295, 365-381.

Awad, A. B., Ferger, S. L. \& Fink, C. S. (1990). Effect of dietary fat on the lipid composition and utilization of short-chain fatty acids by rat colonocytes. Lipids 25, 316-320.

Awad, A. B., Horvath, P. J. \& Andersen, M. S. (1991). Influence of butyrate on lipid metabolism, survival, and differentiating of colon cancer cells. Nutrition and Cancer 16, 125-133.

Babayan, V. K. (1987). Medium chain triglycerides and structured lipids. Lipids 22, 421-423.

Bach, A. C. \& Babayan, V. K. (1982). Medium-chain triglycerides: an update. American Journal of Clinical Nutrition 36, 950-962.

Bach, A. C., Guisard, D., Debry, G. \& Metais, P. (1974). Metabolic effects following a medium chain triglyceride load in dogs. Influence of the perfusion rate. Archives Internationales de Physiologie et de Biochimie 82, 1974.

Bach, A. C., Schirardin, H., Bauer, M. \& Weryha, A. (1977). Ketogenic response to medium chain triglyceride load in the rat. Journal of Nutrition 107, 1863.

Bach, A. C., Storck, D. \& Meraihi, Z. (1988). Medium-chain triglycerides-based fat emulsion: an alternative energy supply in stress and sepsis. Journal of Parenteral and Enteral Nutrition 12, 82S-88S.

Barnard, J. A. \& Warwick, G. (1992). Sodium butyrate rapidly induces 'enterocytic-like' differentiation and growth inhibition of HT-29 cells. Gastroenterology 102, A199.

Bartlet, D., Charsland, S. \& Torosian, M. (1992). Differential effect of medium- and long-chain triglycerides on tumor growth and metastasis. Journal of Parenteral and Enteral Nutrition 16, $26 \mathrm{~S}$.

Bartram, H. P., Scheppach, W., Englert, S., Dusel, G., Richter, A., Richter, F. \& Kasper, H. (1995). Effects of deoxycholic acid and butyrate on mucosal prostaglandin $\mathrm{E} 2$ release and cell proliferation in the human sigmoid colon. Journal of Parenteral and Enteral Nutrition 19, 182-186.

Bartram, H. P., Scheppach, W., Schmidt, H., Hofmann, A., Dusel, G., Richter, F., Richter, A. \& Kasper, H. (1993). Proliferation of human colonic mucosa as an intermediate biomarker of carcinogenesis: effects of butyrate, deoxycholate, calcium, ammonia, and pH. Cancer Research 53, 3283-3288.

Bell, L. \& Williams, L. (1979). Histochemical demonstration of alkaline phosphatase in human large intestine, normal and diseased. Histochemistry 60, 84-90.

Bennegård, K., Lindmark, L., Wickström, I., Scherstén, T. \& Lundholm, K. (1984). A comparative study of the efficiency of intragastric and parenteral nutrition in man. American Journal of Clinical Nutrition 40, 752-757.

Binder, H. J. \& Mehta, P. (1989). Short chain fatty acids stimulate active sodium and chloride absorption in vitro in the rat distal colon. Gastroenterology 96, 989-996.

Binder, H. J. \& Mehta, P. (1990). Characterization of butyrate-dependent electroneutral Na-Cl absorption in the rat distal colon. European Journal of Physiology 417, 365-369.

Bishop, P. R., Warwick, G. J., Gishan, F. K. \& Barnard, J. A. (1992). Sodium butyrate upregulates $\mathrm{Na}^{+}-\mathrm{H}^{+}$ exchanger mRNA and transport activity in CaCo-2 cells. Gastroenterology 102, A358.

Boffa, L. C., Lupton, J. R., Mariani, M. R., Ceppi, M., Newmark, H. L., Scalmati, A. \& Lipkin, M. (1992). Modulation of colonic epithelial cell proliferation, histone acetylation, and luminal short-chain fatty acids by variation of dietary fiber (wheat bran) in rats. Cancer Research 52, 5906-5912.

Boffa, L. C., Vidali, G., Mann, R. S. \& Allfrey, V. G. (1978). Suppression of histone deacetylation in vivo and in vitro by sodium butyrate. Journal of Biological Chemistry 253, 3364-3366.

Boffa, L., Vidali, G., Mann, R. \& Allfrey, V. (1981). Manifold effects of sodium butyrate on nuclear function. Selective and reversible inhibition of phosphorylation of histones $\mathrm{H} 1$ and $\mathrm{H} 2 \mathrm{~A}$ and impaired methylation of lysine and arginine residues in nuclear protein fractions. Journal of Biological Chemistry 256, 9612-9621.

Bohmer, T., Rydning, A. \& Solberg, H. E. (1974). Carnitine levels in human serum in health and disease. Clinica Chimica Acta 57, 55-61.

Bos, J. L., Fearon, E. R., Hamilton, S. R., Verlaan-de Vries, M., van Boom, J. H., van der Eb, A. J. \& Vogelstein, B. (1987). Prevalence of ras gene mutations in human colorectal cancers. Nature 327, $293-297$.

Bowling, T. E., Raimundo, A. H., Grimble, G. K. \& Silk, D. B. A. (1993). Reversal by short-chain fatty acids of colonic fluid secretion induced by enteral feeding. Lancet 342, 1266-1268.

Bradburn, D. M., Mathers, J. C., Gunn, A., Burn, J., Chapman, P. D. \& Johnston, D. A. (1993). Colonic fermentation of complex carbohydrates in patients with familial adenomatous polyposis. Gut 34, $630-636$.

Bremer, J. (1980). Carnitine and its role in fatty acid metabolism. Trends in Biochemical Sciences 2, 207. 
Bustos-Fernandez, L. B., Gonzalez, E., Marzi, A. \& Ledesma Depaullo, M. I. (1971). Fecal acidorrhea. New England Journal of Medicine 284, 295-298.

Butler, R. N., Stafford, I., Triantafillos, E., O'Dee, C. D., Jarrett, I. G., Fettman, M. J. \& RobertsThompson, I. C. (1990). Pyruvate sparing by butyrate and propionate in proliferating colonic epithelium. Comparative Biochemistry and Physiology 97B, 333-337.

Butzer, J. D., Parmar, R. \& Dalal, V. (1995). Butyrate enemas stimulate mucosal repair in an experimental colitis in the rat. Gastroenterology 108 , A276.

Chehab, F. F., Kan, Y. W., Law, M. L., Hartz, J., Kao, F.-T. \& Blostein, R. (1987). Human placental $\mathrm{Na}^{+}, \mathrm{K}^{+}$-ATPase $\alpha$ subunit: cDNA cloning, tissue expression, DNA polymorphism, and chromosomal localization. Proceedings of the National Academy of Sciences, USA 84, 7901-7905.

Christman, J. K., Weich, N., Schoenbrun, B., Schneidman, N. \& Acs, G. (1980). Hypomethylation of DNA during differentiation of Friend erythroleukemia cells. Journal of Cell Biology 86, 366-370.

Chung, Y. S., Song, I. S., Erickson, R. H., Sleisenger, M. H. \& Kim, Y. S. (1985). Effect of growth and sodium butyrate on brush border membrane associated hydrolases in human colorectal cancer cell lines. Cancer Research 45, 2976-2982.

Colony, P. C. (1989). The identification of cell types in the normal adult colon. In Cell and Molecular Biology of Colon Cancer, pp. 2-21 [L. H. Augenlicht, editor]. Boca Raton: CRC Press.

Cotter, R., Taylor, C. A., Johnson, R. \& Rowe, W. B. (1987). A metabolic comparison of a pure long-chain triglyceride lipid emulsion (LCT) and various medium-chain triglyceride (MCT)-LCT combination emulsion in dogs. American Journal of Clinical Nutrition 45, 927-939.

Cousenes, L. S., Gallwitz, D. \& Alberts, B. M. (1979). Different accessibilities in chromatin to histone acetylase. Journal of Biological Chemistry 254, 1716-1723.

Cummings, J. H. (1981). Short chain fatty acids in the human colon. Gut 22, 763-779.

Cummings, J. H. \& Branch, W. J. (1990). Fermentation and production of short-chain fatty acids in human large intestine. In Dietary Fiber: Basic and Clinical Aspects, pp. 131-152 [G. G. Vahouny and D. Kritchevsky, editors]. New York: Plenum Press.

Cummings, J. H., Pomare, E. W., Branch, W. J., Naylor, C. P. E. \& Macfarlane, G. T. (1987). Short chain fatty acids in human large intestine, portal, hepatic, and venous blood. Gut 28, 1221-1227.

Czerniak, B., Herz, F., Westo, R. P. \& Koss, L. G. (1987). Modification of H-ras oncogene p-21 expression and cell cycle progression in the human colon cancer cell line HT-29. Cancer Research 47, 2826-2830.

Dawes, R. F. H., Royle, G. T., Dennison, A. R., Crave, P. J. \& Ball, M. (1986). Metabolic studies of a lipid emulsion containing medium-chain triglyceride in perioperative and total parenteral nutrition infusions. World Journal of Surgery 10, 38-46.

Deckelbaum, R. J., Hamilton, J. A., Carpentier, Y. A., Moser, A., Bengtsson-Olivecrona, G., Butbul, E., Gutman, A. \& Olivecrona, T. (1990). Medium-chain versus long-chain triacylglycerol emulsion hydrolysis by lipoprotein lipase and hepatic lipase: implication for the mechanisms of lipase action. Biochemistry $\mathbf{2 9}$, 1136-1142.

DeCosse, J. J., Miller, H. H. \& Lesser, M. L. (1989). Effect of wheat fiber and vitamins C and E on rectal polyps in patients with familial adenopolyposis. Journal of the National Cancer Institute 81, 1290-1297.

DeMichele, S., Karlstad, M. D., Babayan, V. K., Istfan, N., Blackburn, G. L. \& Bistrian, B. R. (1988). Enhanced skeletal muscle and liver protein synthesis with structured lipid in enterally fed burned rats. Metabolism: Clinical and Experimental 37, 787-795.

Demigné, C. \& Rémésy, C. (1985). Stimulation of absorption of volatile fatty acids and minerals in cecum of rats adapted to a very high fiber diet. Journal of Nutrition $115,53-60$.

Deng, G., Liu, G., Hu, L., Gum, J. R. \& Kim, Y. S. (1992). Transcriptional regulation of the human placental-like alkaline phosphatase gene and mechanisms involved in its induction by sodium butyrate. Cancer Research 52, 3378-3383.

Deschner, E. E., Ruperto, J. F., Lupton, J. R. \& Newmark, H. L. (1990). Dietary butyrate (tributyrin) does not enhance AOM-induced colon tumorigenesis. Cancer Letters 52, 79-82.

Dexter, D. L., Lee, E. S., Bliven, S. F., Glicksman, A. S. \& Leith, J. T. (1984). Enhancement by $\mathrm{N}$-methylformamide of the effect of ionizing radiation on qa human colon tumor xenografted in nude mice. Cancer Research 44, 4942-4946.

Ekman, L., Wretlind, A. \& Moldawer, L. (1987). New developments in lipid emulsions for parenteral nutrition. Infusionstherapie und Klinische Ernahrung 14, 4-8.

Engelhardt, W. v. (1995). Absorption of short-chain fatty acids from the large intestine. In Physiological and Clinical Aspects of Short-Chain Fatty Acids, pp. 149-170 [J. H. Cummings, J. L. Rombeau and T. Sakata, editors]. Cambridge: Cambridge University Press. 
Engelhardt, W. v. \& Rechkemmer, G. (1983). Absorption of inorganic ions in short chain fatty acids in the colon of mammals. In Intestinal Transport. Fundamental and Comparative Aspects, pp. $26-45$ [M. Gilles-Baillien and R. Gilles, editors]. Berlin: Springer-Verlag.

Fearon, E. R. \& Vogelstein, B. (1990). A genetic model for colorectal tumorigenesis. Cell 61, 759-767.

Foss, F. M., Veillette, A., Sartor, O., Rose, N. \& Bolen, J. B. (1989). Alterations in the expression of pp60 $0^{\text {c-src }}$ and $\mathrm{p} 56^{\mathrm{lck}}$ associated with butyrate-induced differentiation of human colon carcinoma cells. Oncogene Research 5, 13-23.

Frankel, W. L., Lew, J., Su, B., Bain, A., Klurfeld, D., Einhorn, E., MacDermott, R. P. \& Rombeau, J. L. (1994). Mediation of the trophic effects of short-chain fatty acids on the rat jejunum and colon. Gastroenterology 106, 375-380.

Freeman, H. J. (1986). Effects of differing concentrations of sodium butyrate on 1,2-dimethylhydrazineinduced rat intestinal neoplasia. Gastroenterology 91, 596-602.

Friedel, D. \& Levine, G. M. (1992). Effect of short-chain fatty acids on colonic function and structure. Journal of Parenteral and Enteral Nutrition 16, 1-4.

Gibson, P. R., Moeller, I., Kagelari, O., Folino, M. \& Young, G. P. (1991). Contrasting effects of butyrate on differentiation of neoplastic and non-neoplastic colonic epithelial cells. Journal of Gastroenterology and Hepatology 7, 165-172.

Gibson, P. R. \& Pavli, P. (1992). Pathogenic factors in inflammatory bowel disease. I. Ulcerative colitis. Digestive Diseases and Sciences 10, 17-28.

Glotzer, D. J., Glick, M. E. \& Goldman, H. (1981). Ptitis and colitis following diversion of the fecal stream. Gastroenterology 80, 438-441.

Goodenough, R. D. \& Wolfe, R. R. (1984). Effect of total parenteral nutrition on free fatty acid metabolism in burn patients. Journal of Parenteral and Enteral Nutrition 8, 357-360.

Goodlad, R. A. \& Write, N. A. (1983). Effects of addition of kaolin or cellulose to an elemental diet on intestinal cell proliferation in the rat. British Journal of Nutrition 50, 91-98.

Gordon, E. E. \& Duger, J. (1975). Experimental hyperosmolar diabetic syndrome. Ketogenic response to medium-chain triglycerides. Diabetes 24, 301.

Gregoire, R., Yeung, K. S., Stadler, J., Stern, H. S., Kashtan, H., Neil, G. \& Bruce, W. R. (1991). Effect of high-fat and low-fiber meals on the cell proliferation activity of colorectal mucosa. Nutrition and Cancer 15, $21-26$.

Guillemot, F., Colombel, J. F., Neut, C., Verplanck, N., Lecomte, M., Romond, C., Paris, J. C. \& Cortot, A. (1991). Treatment of diversion colitis by short-chain fatty acids. Diseases of the Colon and Rectum 34, 861-864.

Guisard, D. \& Debry, G. (1972). Metabolic effects of a medium chain triglyceride emulsion injected intravenously in man. Hormone and Metabolic Research 4, 509.

Hamawy, K. J., Georgieff, M., Pomposelli, J. J., Bistrian, B. R. \& Blackburn, G. (1985a). The effect of thermal injury on oxidation and distribution of various lipid emulsions. Journal of Parenteral and Enteral Nutrition 9, 114.

Hamawy, K. J., Moldawer, L. L., Georgieff, M., Valicenti, A. J., Babayan, V. K., Bistrian, B. R. \& Blackburn, G. L. (1985b). The effect of lipid emulsions on reticuloendothelial system function in the injured animal. Journal of Parenteral and Enteral Nutrition 9, 559-565.

Harig, J. M., Soergel, K. H., Komorowski, R. A. \& Wood, C. M. (1989). Treatment of diversion colitis with short-chain fatty acid irrigation. New England Journal of Medicine 320, 23-28.

Hashim, S. A., Arteaga, A. \& Van Itallie, T. B. (1960). Effect of saturated medium-chain triglycerides on serum lipids in man. Lancet $\mathbf{i}, 105$.

Hashim, S. A., Roholt, H. B. \& Van Itallie, T. B. (1962). Pancreatogenous steatorrhea treated with medium-chain triglycerides. Clinical Research 10, 394.

Hashim, S. A. \& Tantibhedyangkul, P. (1987). Medium chain triglyceride in early life: effects on growth of adipose tissue. Lipids 22, 429-434.

Herschel, D. A., Argenzio, R. A., Southworth, M. \& Stevens, C. E. (1981). Absorption of volatile fatty acids, $\mathrm{Na}$ and $\mathrm{H}_{2} \mathrm{O}$ by the colon of the dog. American Journal of Veterinary Research 42, 1118-1124.

Herz, F., Schermer, A., Halwer, M. \& Bogart, L. H. (1981). Alkaline phosphatase in HT-29, a human colon cancer cell line: influence of sodium butyrate and hyperosmolality. Archives of Biochemistry and Biophysics 210, 581-591.

Higgins, P. J. (1989). Antigenic and cytoarchitectural 'markers' of differentation pathways in normal and malignant colonic epithelial cells. In Molecular Biology of Colon Cancer, pp. 112-132 [L. H. Augenlicht, editor]. Boca Raton, FL: CRC Press. 
Hill, J. O., Peters, J. C., Yang, D., Sharp, T., Kaler, M., Abumrad, N. N. \& Greene, H. L. (1989). Thermogenesis in humans during overfeeding with triglycerides. Metabolism 38, 641-648.

Hogben, C., Tocco, D., Brodie, B. B. \& Schanker, L. (1959). On the mechanism of intestinal absorption of drugs. Journal of Pharmacology and Experimental Therapeutics 125, 275-282.

Holtug, K., Rasmussen, H. S. \& Mortensen, P. B. (1992). An in vitro study of short-chain fatty acid concentrations, production and absorption in pig (Sus scrofa) colon. Comparative Biochemistry and Physiology 103, 189-197.

Hoverstad, T. (1986). Standards of short-chain fatty acid absorption in man. Scandinavian Journal of Gastroenterology 21, 257-260.

Howe, G. R., Benito, E., Castelleto, R., Cornée, J., Estève, J., Gallagher, R. P., Iscovich, J. M., Deng-ao, J., Kaaks, R., Kune, G. A., Kune, S., L'Abbé, K. A., Lee, H. P., Lee, M., Miller, A. B., Peters, R. K., Potter, J. D., Riboli, E., Slattery, M. L., Trichopoulos, D., Tuyns, A., Tzonou, A., Whittemore, A. S., Wu-Williams, A. H. \& Shu, Z. (1992). Dietary intake of fiber and decreased risk of cancers of the colon and rectum: evidence from the combined analysis of 13 case-control studies. Journal of the National Cancer Institute 84, 1887-1896.

Ito, F. \& Chou, J. Y. (1984). Induction of placental alkaline phosphatase biosynthesis of sodium butyrate. Journal of Biological Chemistry 259, 2526-2530.

Jacobs, L. R. (1983). Effects of dietary fiber on mucosal growth and cell proliferation in the small intestine of the rat: a comparison of oat bran, pectin and guar with total fiber deprivation. American Journal of Clinical Nutrition 37, 954-960.

Jacobs, L. R. (1986). Relationship between dietary fiber and cancer: metabolic, physiologic, and cellular mechanism. Proceedings of the Society of Experimental Biology and Medicine 182, 299-310.

Jacobs, L. R. (1988). Role of dietary factors in cell replication and colon cancer. American Journal of Clinical Nutrition 48, 775-779.

Jacobs, L. R. (1990). Influence of soluble fibers on experimental colon carcinogenesis. In Dietary Fiber: Basic and Clinical Aspects, pp. 389-403 [G. B. Vahouny and D. Kritchevsky, editors]. New York: Plenum Press.

Jacobs, M. H. (1940). Some aspects of cell permeability to weak electrolytes. Cold Spring Harbor Symposia on Quantitative Biology 8, 30-39.

Janne, P., Carpenter, Y. \& Willems, G. (1977). Colonic mucosal atrophy induced by a liquid elemental diet in rats. American Journal of Digestive Diseases 22, 808-812.

Jass, J. R. (1985). Diet, butyric acid and differentiation of gastrointestinal tract tumours. Medical Hypotheses $18,113-118$.

Jiang, Z., Zhang, S., Wang, X., Yang, N., Zhu, Y. \& Wilmore, D. (1993). A comparison of medium-chain and long-chain triglycerides in surgical patients. Annals of Surgery 217, 175-184.

Kameyama, J., Narui, H., Imui, M. \& Sasaki, I. (1984). Energy level in large intestinal mucosa in patients with ulcerative colitis. Tohoku Journal of Experimental Medicine 143, 253-254.

Kashtan, H., Stern, H. S., Jenkins, D. J. A., Jenkins, A. L., Thompson, L. U., Ha, K., Marcon, N., Minkin, S. \& Bruce, W. R. (1992). Colonic fermentation and markers of colorectal-cancer risk. American Journal of Clinical Nutrition 55, 723-728.

Kim, Y. S., Tsao, D., Siddiqui, B., Whitehead, J. S., Arnstein, P., Bennette, J. \& Hicks, J. (1980). Effects of sodium butyrate and dimethylsulfoxide on biochemical properties of human colon cancer cells. Cancer $\mathbf{4 5}$, 1185-1192.

Klein, S. \& Miles, J. M. (1994). Metabolic effects of long-chain and medium-chain triglyceride emulsions in humans. Journal of Parenteral and Enteral Nutrition 18, 396-397.

Knudsen, K. E., Jensen, B. B. \& Hansen, I. (1993). Oat bran but not a $\beta$-glucan enriched oat fraction enhances butyrate production in the large intestine of pigs. Journal of Nutrition 123, 1235-1247.

Koruda, M. J., Rolandelli, R. H., Bliss, D. Z., Hastings, J., Rombeau, J. L. \& Settle, R. G. (1990). Parenteral nutrition supplemented with short-chain fatty acids: effect on the small-bowel mucosa in normal rats. American Journal of Clinical Nutrition 51, 685-689.

Kripke, S. A., Fox, A. D., Berman, J. M., Settle, R. G. \& Rombeau, J. L. (1989). Stimulation of intestinal mucosal growth with intracolonic infusion of short-chain fatty acids. Journal of Parenteral and Enteral Nutrition 13, 109-116.

Kruh, J. (1982). Effect of sodium butyrate, a new pharmacological agent, on cells in culture. Molecular Cell Biology 42, 65-82.

Kruh, J., Defer, N. \& Tichonicky, L. (1995). Effects of butyrate in cell proliferation and gene expression. In Physiological and Clinical Aspects of Short-Chain Fatty Acids, pp. 275-288 [J. H. Cummings, J. L. Rombeau and T. Sakata, editors]. Cambridge: Cambridge University Press. 
Kruh, J., Tichonicky, L. \& Defer, N. (1994). Effect of butyrate on gene expression. In Short-Chain Fatty Acids, pp. 135-147 [J. Cummings, H. J. Binder and K. Soergel, editors]. Boston: Kluwer Academic Publishers.

Kvietys, P. R. \& Granger, D. N. (1981). Effects of volatile fatty acids on blood flow and oxygen uptake by the dog colon. Gastroenterology 80, 962-969.

Lanser, M. \& Saba, T. (1981). Neutrophil-mediated lung localization of bacteria: a mechanism for pulmonary injury. Surgery $90,473-481$.

Lee, D. K., Chapkin, R. S. \& Lupton, J. R. (1993). Dietary fat and fiber modulate colonic cell proliferation in an interactive site-specific manner. Nutrition and Cancer 20, 107-118.

Lipkin, M. (1988). Biomarkers of increased susceptibility to gastrointestinal cancer: new application to studies of cancer prevention in human subjects. Cancer Research 48, 235-245.

Longo, W. E., Ballantyne, G. H., Savoca, P. E., Adrian, T. E., Blichik, A. J. \& Modlin, I. M. (1991). Short-chain fatty acid release of peptide $\mathrm{YY}$ in the isolated rabbit distal colon. Scandinavian Journal of Gastroenterology 26, 442-448.

Luciano, L., Reale, E., Rechkemmer, G. \& Engelhardt, W. v. (1984). Structure of zonulae occludentes and permeability of epithelium to short-chain fatty acid in the proximal and distal colon of guinea pig. Journal of Membrane Biology 82, 145-156.

Lupton, J. R. \& Kurtz, P. P. (1993). Relationship of colonic luminal short-chain fatty acids and pH to in vivo cell proliferation in rats. Journal of Nutrition 123, 1522-1530.

Lutz, T. \& Scharrer, E. (1991). Effect of short-chain fatty acids on calcium absorption by the rat. Experimental Physiology 76, 615-618.

Macfarlane, G. T., Gibson, G. R. \& Cummings, J. H. (1992). Comparison of fermentation reactions in different regions of the human colon. Journal of Applied Bacteriology 72, 54-64.

Macfarlane, G. T., Gibson, G. R. \& Macfarlane, S. (1994). Short-chain fatty acid and lactate production by human intestinal bacteria grown in batch and continuous culture. In Short-Chain Fatty Acids, pp. 44-60 [J. Cummings, H. J. Binder and K. Soergel, editors]. Boston: Kluwer Academic Publishers.

McIntyre, A., Gibson, P. R. \& Young, G. P. (1993). Butyrate production from dietary fibre and protection against large bowel cancer in a rat model. Gut 34, 386-391.

McIntyre, A., Young, G. P., Taranto, T., Gibson, P. R. \& Ward, P. B. (1991). Different fibers have different regional effects on luminal contents of rat colon. Gastroenterology 101, 1274-1281.

McNeil, N. I. (1984). Contribution of the large intestine to energy supplies in man. American Journal of Clinical Nutrition 39, 338-342.

McNeil, N. I., Cummings, J. H. \& James, W. P. T. (1978). Short-chain fatty acid absorption by the human large intestine. Gut 19,819-822.

Maczulak, A. E., Wolin, M. J. \& Miller, T. L. (1983). Amounts of viable anaerobes, methanogens, and bacterial fermentation products in feces of rats fed high-fiber or fiber-free diets. Applied and Environmental Microbiology 59, 657-662.

Magnussen, K., Rönnholm, H., Sandberg, G., Lindmark, L., Enekull, U. \& Ekman, L. (1986). Effect of structured triglycerides on protein synthesis in liver and muscle tissue during TPN in an injured rat model. Clinical Nutrition 5, 141.

Maiz, A., Yamazaki, K., Sobrado, J., Babayan, V. K., Moldawer, L. L., Bistrian, B. R. \& Blackburn, G. (1984a). Hypocaloric lipid emulsions and amino acid metabolism in injured rats. Journal of Parenteral and Enteral Nutrition 8, 361.

Maiz, A., Yamazaki, K., Sobrado, J., Babayan, V. K., Moldawer, L. L., Bistrian, B. R. \& Blackburn, G. $(1984 b)$. Protein metabolism during total parenteral nutrition in injured rats using medium-chain triglycerides. Metabolism 33, 901-904.

Marty, J. \& Vernay, M. (1984). Absorption and metabolism of the volatile fatty acids in the hind gut of the rabbit. British Journal of Nutrition 51, 265-277.

Mascioli, E. A., Babayan, V. K., Bistrian, B. R. \& Blackburn, G. (1988). Novel triglycerides for special medical purpose. Journal of Parenteral and Enteral Nutrition 12, 127S-132S.

Miles, J. M. (1991). Intravenous fat emulsions in nutritional support. Current Opinion in Gastroenterology 7 , 306-311.

Miles, J. M., Cattalini, M., Sharbrough, F. W., Wold, L. E., Wharen, R. E., Gerich, J. E. \& Haymond, M. W. (1991). Metabolic and neurologic effects of an intravenous medium-chain triglyceride emulsion. Joumal of Parenteral and Enteral Nutrition 15, 37-41.

Mitchell, M. E. (1978). Carnitine metabolism in human subjects. I: normal metabolism. American Journal of Clinical Nutrition 31, 293-306. 
Mok, K. T., Maiz, A., Yamazaki, K., Sobrado, J., Babayan, V., Moldawer, L., Bistrian, B. \& Blackburn, G. (1984). Structured medium-chain and long-chain emulsions are superior to physical mixtures in sparing body protein in the burned rat. Metabolism 33, 910-915.

Morita, A., Tsao, D. \& Kim, Y. S. (1982). Effect of sodium butyrate on alkaline phosphatase in HRT-18, a human rectal cancer cell line. Cancer Research 42, 4540-4545.

Mortensen, P. B., Holtug, K., Bonnen, H. \& Clausen, M. R. (1990). The degradation of amino acids, proteins, and blood to short-chain fatty acids in colon is prevented by lactulose. Gastroenterology $\mathbf{9 8}$, $353-360$.

Moyer, E., Wennberg, A. \& Ekman, L. (1989). A metabolic comparison between MCT, MCT/LCT and structured lipids. Clinical Nutrition $\mathbf{8}, 83$.

Murray, R. D., McClung, H. J., Li, B. U. \& Ailabouni, A. (1987). Short-chain fatty acid profile in the colon of newborn piglets using fecal water analysis. Pediatric Research 22, 720-724.

Nyman, M. \& Asp, N. G. (1982). Fermentation of dietary fibre components in rat intestinal tract. British Journal of Nutrition 47, 357-366.

Otaka, M., Singhal, A. \& Hakomori, S. (1989). Antibody-mediated targeting of differentiation inducers to tumor cells: inhibition of colonic cancer cell growth in vitro and in vivo. Biochemical and Biophysical Research Communications 158, 202-208.

Parker, M., de Haan, J. \& Gevers, W. (1985). DNA hypermethylation in sodium butyrate-treated WI-38 fibroblasts. Journal of Biological Chemistry 261, 2786-2790.

Pressman, B. C. \& Lardy, H. A. (1956). Effects of surface active agents on the latent ATPase of mitochondria. Biochimica et Biophysica Acta 21, 458-466.

Rajendran, V. M. \& Binder, H. J. (1994). Short-chain fatty acid stimulation of electroneutral Na-Cl absorption: role of apical SCFA-HCO $\mathrm{H}_{3}$ and SCFA-CI exchanges. In Short-Chain Fatty Acids, pp. 104-116 [J, Cummings, H. J. Binder and K. Soergel, editors]. Boston: Kluwer Academic Publishers.

Rasmussen, H. S. , Holtug, K., Ynggård, C. \& Mortensen, P. B. (1988). Faecal concentrations and production rates of short-chain fatty acids in normal neonates. Acta Paediatrica Scandinavica 77, 365-368.

Rast1, E. \& Swetly, P. (1978). Expression of poly-(adenosine diphosphate-ribose) polymerase activity in erythroleukemic mouse cells during cell cycle and erythropoietic differentiation. Journal of Biological Chemistry 253, 4333-4340.

Rechkemmer, G. \& Engelhardt, W. v. (1988). Concentration- and pH-dependence of short-chain fatty acid absorption in the proximal and distal colon of guinea pig. Comparative Biochemistry and Physiology 91A, $569-663$.

Rechkemmer, G., Rönnau, K. \& Engelhardt, W. v. (1988). Fermentation of polysaccharides and absorption of short chain fatty acids in the mammalian hindgut. Comparative Biochemistry and Physiology 90A, 563-568.

Rechkemmer, G., Wahl, M., Kuschinsky, W. \& Engelhardt, W. v. (1986). pH-microclimate at the luminal surface of the intestinal mucosa of guinea pigs. Pflugers Archiv - European Journal of Physiology 407, 33-44.

Reeves, R. \& Dserjesi, P. (1979). Sodium butyrate induces new gene expression in Friend erythroleukemic cells. Journal of Biological Chemistry 254, 4383-4390.

Robinson, A. M. \& Williamson, D. H. (1980). Physiological roles of ketone bodies as substrates and signals in mammalian tissues. Physiological Reviews 60, 143-187.

Rodriguez, N., Schwenk, W. F., Beaufrere, B., Miles, J. M. \& Haymond, M. W. (1986). Trioctanoin infusion increases in vivo leucine oxidation: a lesson in isotope modeling. American Journal of Physiology 251, E343-E348.

Roediger, W. E. W. (1980a). Anaerobic bacteria support the metabolic welfare of the colonic mucosa in man. Gut 21, 793 .

Roediger, W. E. W. (1980b). The colonic epithelium in ulcerative colitis: an energy deficient disease? Lancet ii, $712-715$.

Roediger, W. E. W. (1982). Utilization of nutrients by isolated epithelial cells of the rat colon. Gastroenterology 83, 424-429.

Roediger, W. E., Lawson, M. J., Kwok, V., Grant, A. K. \& Pannall, P. R. (1984). Colonic bicarbonate output as a test of disease activity in ulcerative colitis. Journal of Clinical Pathology 37, 704-707.

Roediger, W., Schapel, G., Lawson, M., Radcliffe, B. \& Nance, S. (1986). Effect of 5-aminosalicylic acid (5-ASA) and other salicylates on short-chain fat metabolism in the colonic mucosa. Biochemical Pharmacology 35, 221-225.

Rolandelli, R. H., Koruda, M. J., Settle, R. \& Rombeau, J. L. (1986). Effects of intraluminal infusion of short-chain fatty acids on the healing of colonic anastomosis in the rat. Surgery 100, 198-203. 
Rombeau, J. L., Kripke, S. A. \& Settle, R. G. (1990). Short-chain fatty acids: production, absorption, metabolism, and intestinal effects. In Dietary Fiber: Basic and Clinical Aspects, pp. 317-339 [G. B. Vahouny and D. Kritchevsky, editors]. New York: Plenum Press.

Rönnau, K., Guth, D. \& Engelhardt, W. v. (1989). Absorption of dissociated and undissociated short-chain fatty acids across the colonic epithelium of guinea pig. Quarterly Journal of Experimental Physiology 74, $511-519$.

Rübsamen, K., Hume, I. D. \& Engelhardt, W. v. (1982). Physiology of the rock hyrax. Comparative Biochemistry and Physiology 72, 271-277.

Ruppin, H., Bar-Mei, S., Soergel, K., Wood, C. M. \& Schmitt, M. G. Jr (1980). Absorption of short-chain fatty acids by the colon. Gastroenterology 78, 1500-1507.

Sailer, D. \& Berg, G. (1974). Medium-chain triglycerides clinical physiology and application. Zeitschrift für Ernahrungswissenschaft 13, 6-17.

Sailer, D. \& Muller, M. (1981). Medium chain triglycerides in parenteral nutrition. Journal of Parenteral and Enteral Nutrition 5, 115.

Sakata, T. (1984). Influence of short-chain fatty acids on epithelial cell division of digestive tract. Journal of Experimental Physiology 69, 639-648.

Sakata, T. (1987). Stimulatory effect of short-chain fatty acids on epithelial cell proliferation in the rat intestine: a possible explanation for trophic effects of fermentable fibre, gut microbes and luminal trophic factors. British Journal of Nutrition 58, 95-101.

Sakata, T. (1988). Depression of intestinal epithelial cell production rate by hindgut bypass in rats. Scandinavian Journal of Gastroenterology 23, 1200-1202.

Sakata, T. \& Engelhardt, W. v. (1983). Stimulatory effects of short chain fatty acids on the epithelial cell proliferation in rat large intestine. Comparative Biochemistry and Physiology 74A, 459-462.

Sandberg, G., Enekull, U. \& Ekman, L. (1985). Leucine oxidation and energy metabolism during administration of fat emulsions with different types of triglycerides. Clinical Nutrition 5, 117.

Sandström, R., Hyltander, A., Körner, U. \& Lundholm, K. (1993). Structured triglycerides to postoperative patients: safety and tolerance study. Journal of Parenteral and Enteral Nutrition 17, 153-157.

Schafer, W. R., Kim, R., Sterne, R. Thorne, J., Kim, S. \& Rine, J. (1989). Genetic and pharmacological suppression of oncogenic mutations in ras genes of yeast and humans. Science 245, 379-385.

Scheppach, W. (1994). Short-chain fatty acids improve epithelia in ulcerative colitis? Speculation on mechanisms. In Short-chain Fatty Acids, pp. 206-213 [J. Cummings, H. J. Binder and K. Soergel, editors]. Boston: Kluwer Academic Publishers.

Scheppach, W. \& Bartram, H.-P. (1993). Experimental evidence for and clinical implications of fiber and artificial enteral nutrition. Nutrition 9, 399-405.

Scheppach, W., Bartram, P., Richter, A., Richter, F., Dusel, G., Liepold, H., Hofstetter, G., Ruthlein, J. \& Kasper, H. (1992a). Effect of short-chain fatty acids on the human colonic mucosa in vitro. Journal of Parenteral and Enteral Nutrition 16, 43-48.

Scheppach, W., Burghardt, W., Bartram, P. \& Kasper, H. (1990). Addition of dietary fiber to liquid formula diets: the pros and the cons. Journal of Parenteral and Enteral Nutrition 14, 204-209.

Scheppach, W., Sommer, H., Kirchner, T., Paganelli, G. M., Bartram, P., Christl, S., Richter, F., Dusel, G. \& Kasper, H. (1992b). Effect of butyrate enemas on the colonic mucosa in distal ulcerative colitis. Gastroenterology 103, 51-56.

Sellin, J. H., De Soignie, R. \& Burlingame, S. (1993). Segmental differences in short-chain fatty acids transport in rabbit colon. Effect of $\mathrm{pH}$ and Na. Journal of Membrane Biology 136, 147-158.

Shore, P. A., Brodie, B. B. \& Hobgen, C. A. M. (1957). The gastric secretion of drugs: a pH partition hypothesis. Journal of Pharmacology 119, 361-369.

Silk, D. B. A. (1989). Fibre and enteral nutrition. Gut 30, 246-264.

Sobrado, J., Moldawer, L., Pomposelli, J., Mascioli, E., Babayan, V., Bistrian, B. \& Blackburn, G. (1985). Lipid emulsions and reticuloendothelial system function in healthy and burned guinea pigs. American Journal of Clinical Nutrition 42, 855-863.

Souleimani, A. \& Asselin, C. (1992). Regulation of proto-oncogene expression by sodium butyrate in the human colon carcinoma cell line CaCo-2. Gastroenterology 102, A400.

Stein, T. P., Fried, R. C., Torosian, M. H., Leskiw, M. J., Schluter, M. D., Settle, R. G. \& Buzby, G. P. (1986). Comparison of glucose, LCT and LCT plus MCT as calorie sources for parenterally nourished septic rats. American Journal of Physiology 250, E312-E318.

Stein, T. P., Presti, M. E., Leskiw, M. J., Torosian, M. E., Settle, R. G., Buzby, G. P. \& Schluter, M. D. (1984). Comparison of glucose, LCT and LCT plus MCT as calorie sources for parenterally nourished rats. American Journal of Physiology 246, E277-E287. 
Stevens, C. E. (1988). Comparative Physiology of the Vertebrate Digestive System. Cambridge: Cambridge University Press.

Stoddart, J. H., Lane, M. A. \& Niles, R. M. (1989). Sodium butyrate suppresses the transforming activity $\mathrm{N}$-ras oncogene in human colon carcinoma cells. Experimental Cell Research 184, 16-27.

Teo, T. C., DeMichele, S. J. \& Selleck, K. (1989). Administration of structured lipid composed of MCT and fish oil reduced net protein catabolism in enterally fed burned rats. Annals of Surgery 210, 100-107.

Thomson, A. B. R. (1978). Intestinal absorption of lipids: influence of the unstirred water layer and bile acid micelle. In Disturbances in Lipid and Lipoprotein Metabolism, pp. 29-55 [J. M. Dietschy, A. M. Gotto and J. A. Ontko, editors]. Bethesda, MD: American Physiological Society.

Titgemeyer, E. C., Bourquin, L. D., Fahey, G. C. \& Garleb, K. A. (1991). Fermentability of various fiber sources by human fecal bacteria in vitro. American Journal of Clinical Nutrition 53, 418-424.

Topping, D. L., Illman, R. J., Clarke, J. M., Trimble, R. P., Jackson, K. A. \& Marsono, Y. (1993). Dietary fat and fiber alter large bowel and portal venous volatile fatty acids and plasma cholesterol but not biliary steroids in pigs. Journal of Nutrition 123, 133-143.

Toribara, N. W., Sack, T. L., Gum, J. R., Ho, S. B., Shively, J. E., Willson, J. K. V. \& Kim, Y. S. (1989), Heterogeneity in the induction and expression of carcinoembryonic antigen-related antigens in human colon cancer cell lines. Cancer Research 49, 3321-3327.

Toscani, A., Soprano, D. R. \& Soprano, K. J. (1988). Molecular analysis of sodium butyrate-induced growth arrest. Oncogene Research 3, 223-238.

Tsao, D., Morita, A., Bella, A., Luu, P. \& Kim, Y. S. (1982). Differential effects of sodium butyrate, dimethylsulfoxide, retinoic acid on membrane-associated antigen, enzymes and glycoproteins of human rectal adenocarcinoma cells. Cancer Research 42, 1052-1058.

Umesaki, Y., Yajima, T., Yokokura, T. \& Mutai, M. (1979). Effect of organic acid absorption on bicarbonate transport in rat colon. Pflügers Archiv - European Journal of Physiology 379, 43-47.

Van Munster, I. P. \& Nagengast, F. M. (1993). The role of carbohydrate fermentation in colon cancer prevention. Scandinavian Journal of Gastroenterology 28, 80-86.

Vernay, M. (1987). Effects of plasma aldosterone on butyrate absorption and metabolism in the rabbit proximal colon. Comparative Biochemistry and Physiology 86, 657-662.

Vidali, G., Boffa, L. C., Bradbury, E. M. \& Allfrey, V. G. (1978). Butyrate suppression of histone deacetylation leads to accumulation of multiacetylated forms of histone $\mathrm{H} 3$ and $\mathrm{H} 4$ and increased DNase I sensitivity of the associated DNA sequences. Proceedings of the National Academy of Sciences, USA 75, 2239.

Vogelstein, B., Fearon, E. R., Hamilton, S. R., Kern, S. E., Preisinger, A. C., Leppert, M., Nakamura, Y., White, R., Smits, A. M. \& Bos, J. L. (1988). Genetic alterations during colorectal-tumor development. New England Journal of Medicine 319, 525.

Walter, A. \& Gutknecht, J. (1984). Monocarboxylic acid permeation bilayer membranes. Journal of Membrane Biology 77, 255-264.

Wan, J. M.-F., Teo, T. C., Babayan, V. K. \& Blackburn, G. L. (1988). Invited comment: lipids and the development of immune dysfunction and infection. Journal of Parenteral and Enteral Nutrition 12, 43S-52S.

Wargovich, M. J., Harris, C., Chen, C. D., Palmer, C., Steele, V. E. \& Kelloff, G. J. (1992). Growth kinetics and chemoprevention of aberrant crypts in the rat colon. Journal of Cell Biochemistry $16 \mathrm{G}, 51-54$.

Weaver, G. A., Krause, J. A., Miller, T. L. \& Wolin, M. J. (1988). Short chain fatty acid distributions of enema samples from a sigmoidoscopy population: an association of high acetate and low butyrate ratios with adenomatous polyps and colon cancer. Gut 29, 1539-1543.

Weaver, G. A., Krause, J. A., Miller, T. L. \& Wolin, M. J. (1992). Cornstarch fermentation by the colonic microbial community yields more butyrate than does cabbage fiber fermentation; cornstarch fermentation rates correlate negatively with methanogenesis. American Journal of Clinical Nutrition 55, 70-77.

Weissman, C., Chiolero, R., Askanazi, J., Gil, K. M., Elwyn, D. \& Kinney, J. M. (1988). Intravenous infusion of a medium-chain triglyceride-enriched lipid emulsion. Critical Care Medicine 16, 1183-1190.

Whitehead, R. H., Young, G. P. \& Bhathal, P. S. (1986). Effects of short chain fatty acids on a new human colon carcinoma cell line (LIM1215). Gut 27, 1457-1463.

Wiley, J. H. \& Leveille, G. A. (1973). Metabolic consequences of dietary medium chain triglycerides in the rat. Journal of Nutrition 113, 829-835.

Willson, J. K. V. (1989). Biology of large bowel cancer. Hematology Oncology Clinics of North America 3, $19-34$

Willumsen, B. M., Christensen, A., Hubbert, N. L., Papageorge, A. G. \& Lowy, D. R. (1984). The p21 ras C-terminus is required for transformation and membrane association. Nature 310, 583-586. 
Windmeuller, H. G. \& Spaeth, A. E. (1978). Identification of ketone bodies and glutamine as the major respiratory fuels in vivo for postoperative rat small intestine. Journal of Biological Chemistry 253, 69-76.

Wolfram, G., Hailer, S. \& Rett, K. (1985). MCT/LCT or LCT emulsion and skeletal muscle - effects on lipoprotein. Clinical Nutrition 4S, 6.

Wolin, M. J. (1981). Fermentation in the rumen and human large intestine. Science 213, 1463-1468.

Wrong, O. M. (1981). Carbohydrates. In The Large Intestine: Its Role in Mammalian Nutrition and Homeostasis, pp. 20-21, 113-114 [O. M. Wrong, C. J. Edmunds and V. S. Chadwick, editors]. New York: Halsted Press.

Yajima, T. (1985). Contractile effect of short-chain fatty acids on the isolated colon of the rat. Journal of Physiology 368, 667-678.

Yeh, Y. Y., Klein, L. B. \& Zee, P. (1978). Long and medium chain triglycerides increase plasma concentrations of ketone bodies in suckling rats. Lipids 3, 566-571.

Yeh, Y. Y. \& Zee, P. (1976). Relation of ketosis to metabolic changes induced by medium chain triglyceride feeding in rats. Journal of Nutrition 106, 58.

Young, G. P. (1990). Dietary fibre in the prevention of colorectal cancer: lessons from standards in animal models. Proceedings of the Nutrition Society of Australia 15, 112-119.

Young, G. P. (1991). Butyrate and the molecular biology of the large bowel. In Short Chain Fatty Acids: Metabolism and Clinical Importance. Report of the Tenth Ross Conference on Medical Research, pp. 39-45 [J. L. Rombeau, J. H. Cummings and T. Sakata, editors]. Columbus, $\mathrm{OH}$ : Ross Laboratories.

Young, G. P. \& Gibson, P. R. (1994). Butyrate and colorectal cancer cell. In Short-Chain Fatty Acids, pp. 148-160 [J. Cummings, H. J. Binder and K. Soergel, editors]. Boston: Kluwer Academic Publishers.

Young, G. P. \& Gibson, P. R. (1995). Butyrate and the human cancer cell. In Physiological and Clinical Aspects of Short-chain Fatty Acids, pp. 319-336 [J. H. Cummings, J. L. Rombeau and T. Sakata, editors]. Cambridge: Cambridge University Press.

Young, G. P., Macrae, F. A., Gibson, P. R., Alexeyeff, M. \& Whitehead, R. (1992). Brush border hydrolases in normal and neoplastic colonic epithelium. Journal of Gastroenterology and Hepatology 7, 347-357. 